\title{
Hypertriglyceridemia: A Neglected Risk Factor for Ischemic Stroke?
}

\author{
Hai-jie Liang, ${ }^{\text {a,b,* }}$ Qing-yi Zhang, ${ }^{\text {a,b,c,d,e,* }}$ Yi-tong Hu, ${ }^{\text {a,b }}$ Guo-qing Liu, ${ }^{\mathrm{b}}$ Rong Qi ${ }^{\mathrm{a}, \mathrm{b}, \mathrm{c}, \mathrm{d}, \mathrm{e}}$ \\ ${ }^{a}$ Department of Pharmacology, School of Basic Medical Sciences, Beijing, China \\ ${ }^{b}$ Key Laboratory of Molecular Cardiovascular Sciences, Ministry of Education, Beijing, China \\ 'State Key Laboratory of Natural and Biomimetic Drugs, Beijing, China \\ ${ }^{\mathrm{d}} \mathrm{NHC}$ Key Laboratory of Cardiovascular Molecular Biology and Regulatory Peptides, Beijing, China

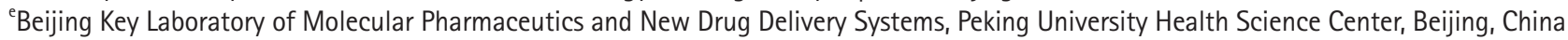

Hypertriglyceridemia is caused by defects in triglyceride metabolism and generally manifests as abnormally high plasma triglyceride levels. Although the role of hypertriglyceridemia may not draw as much attention as that of plasma cholesterol in stroke, plasma triglycerides, especially nonfasting triglycerides, are thought to be correlated with the risk of ischemic stroke. Hypertriglyceridemia may increase the risk of ischemic stroke by promoting atherosclerosis and thrombosis and increasing blood viscosity. Moreover, hypertriglyceridemia may have some protective effects in patients who have already suffered a stroke via unclear mechanisms. Therefore, further studies are needed to elucidate the role of hypertriglyceridemia in the development and prognosis of ischemic stroke.

Keywords Hypertriglyceridemia; Ischemic stroke; Incidence; Prognosis
Correspondence: Rong Qi Department of Pharmacology, School of Basic Medical Sciences, Peking University Health Science Center, 38 Xueyuan Road, Haidian District, Beijing 100191, China Tel: $+86-10-8280-5164$ Fax: +86-10-8280-5164 E-mail: ronaqi@bjmu.edu.cn https://orcid.org/0000-0002-0627-9968

Received: August 12, 2021 Revised: October 25, 2021 Accepted: December 27, 2021

*These authors contributed equally to the manuscript as first author.

\section{Introduction}

Stroke is a highly prevalent disease, especially in developing countries. ${ }^{1,2}$ According to the Guidelines for the Primary Prevention of Stroke published by the American Heart Association/ American Stroke Association (AHA/ASA), the risk factors for stroke include dyslipidemia, overweight and obesity, metabolic syndrome, etc. ${ }^{3,4}$ Hypercholesterolemia is highly prevalent in ischemic stroke patients, and approximately $45 \%$ to $60 \%$ of them are simultaneously affected by it, according to large clinical trials. ${ }^{5,6}$ Although the relationship between hypercholesterolemia and ischemic stroke remains uncertain, ${ }^{7-9}$ the success of statins in the prevention of ischemic stroke confirms the important role of cholesterol, especially low-density lipoprotein cholesterol (LDL-C), in clinical practice. ${ }^{10-12}$ Hypertriglyceridemia, another type of dyslipidemia, has received lesser attention than hypercholesterolemia, as its role in ischemic stroke remains controversial. ${ }^{7,13,14}$ However, an increasing number of studies have found a close relationship between plasma triglycerides (TGs) and the development, duration, and prognosis of ischemic stroke. In this paper, we reviewed the pathophysiology of TG metabolism, the association between hypertriglyceridemia and ischemic stroke, the underlying mechanisms, and its clinical significance.

\section{Triglyceride metabolism and hypertriglyceridemia}

Plasma TG levels are regulated by the balance of synthesis, lipoprotein lipase (LPL)-mediated hydrolysis, and hepatic remnant clearance (Figure 1). ${ }^{15}$ Plasma TGs mainly exist within triglyceride-rich lipoproteins (TRLS), such as chylomicron (CM), very low-density lipoprotein (VLDL), and their remnant particles. Nascent CMs synthesized by enterocytes have a higher 


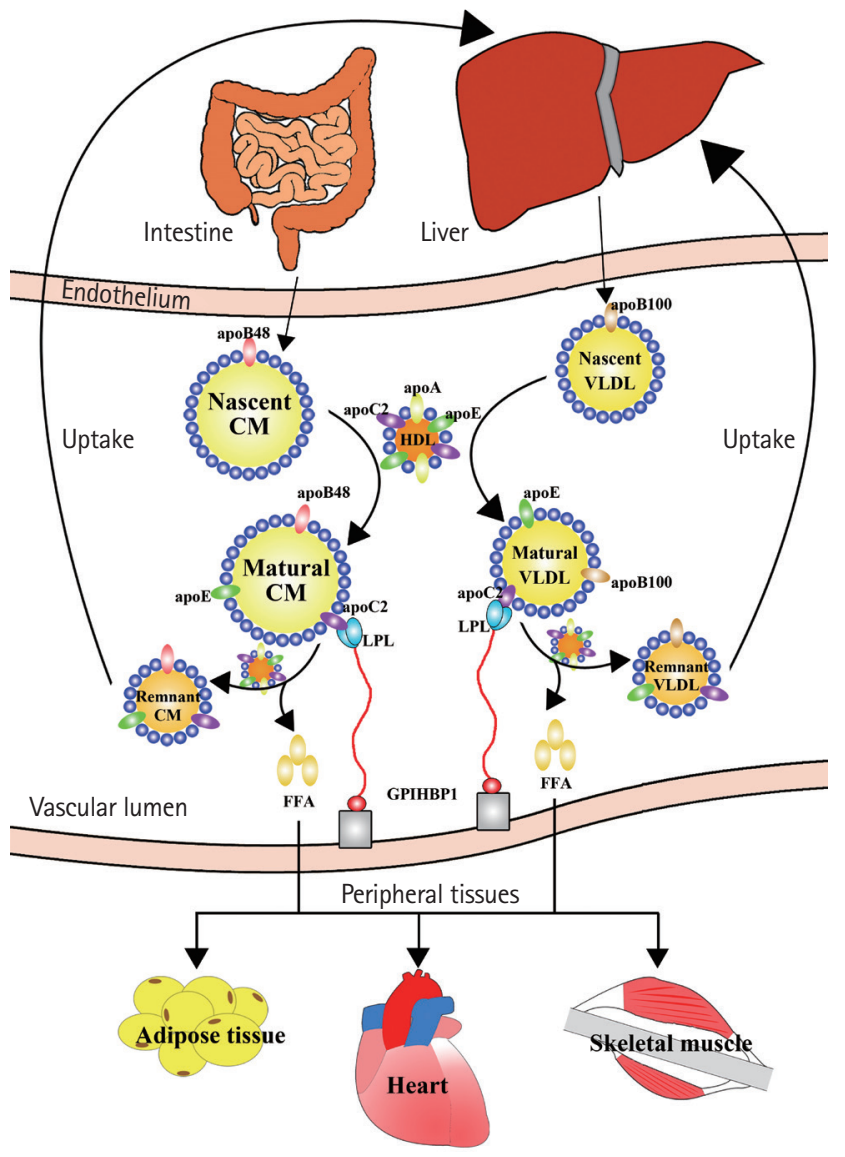

Figure 1. Metabolism of triglycerides. ${ }^{15}$ Triglycerides are incorporated into chylomicron (CM) by enterocytes and into very low-density lipoprotein (VLDL) by hepatocytes. Nascent CM has apolipoprotein B48 (apoB48) on its surface, while nascent VLDL has apolipoprotein B100 (apoB100). After interaction with high-density lipoprotein (HDL), these two types of lipoproteins become mature and can be hydrolyzed by lipoprotein lipase (LPL) anchoring to the vascular endothelium. As a result, free fatty acids (FFAs) are released from CM and VLDL and utilized by peripheral tissues, such as adipose tissue, heart, and skeletal muscle. Mature CM and VLDL become remnant particles after continuous interactions with LPL and HDL and are finally taken up by the liver. GPIHBP1, glycosylphosphatidylinositol anchored high-density lipoprotein binding protein 1.

TG-to-cholesterol mass ratio and primarily consist of apolipoprotein (Apo) B-48 and A-1. ${ }^{16}$ These particles range from 75 to $3,000 \mathrm{~nm}$ in diameter, depending on the dietary lipid mass. ${ }^{17}$ After interaction with high-density lipoprotein (HDL), the nascent $\mathrm{CM}$ becomes mature and acquires $\mathrm{ApoC}$ and $\mathrm{ApoE}$ on its surface. In tissue capillaries, these CMs bind to LPL, which is activated by $\mathrm{ApoC} 2$, thereby inducing lipolysis in TGs. Alternatively, VLDL is constantly synthesized and secreted by the liver and primarily contains TGs with ApoB-100, ApoC, and ApoE on the surface. Nascent VLDL also requires interaction with HDL to become mature and transform into smaller particles as VLDL remnants after lipolysis by LPL. The liver is a major organ that removes remnant particles from the blood, predominantly through mechanisms mediated by receptors, including $A p o E$, the LDL receptor (LDLR) family, and cell-surface heparin sulfate proteoglycans on hepatocytes. ${ }^{18,19}$

Hypertriglyceridemia is characterized by abnormally high blood TG levels. According to the Third Report of the National Cholesterol Education Program-Expert Panel on Detection, Evaluation, and Treatment of High Blood Cholesterol in Adults (NCEP-ATPIII), the concentrations of fasting TGs are stratified into four levels: normal, borderline high, high, and very high (Table 1). ${ }^{20}$ Any factor that interrupts the metabolic process of TGs can result in hypertriglyceridemia. ${ }^{15,21}$ Borderline high TGs (1.70 to $2.25 \mathrm{mmol} / \mathrm{L}$ ) are mostly derived from acquired factors, such as overweight and obesity, physical inactivity, cigarette smoking, excess alcohol intake, and high carbohydrate intake. High values of TGs (2.26 to $5.64 \mathrm{mmol} / \mathrm{L}$ ) generally result from a combination of acquired and genetic factors. Several individuals in this classification have insulin resistance and metabolic syndrome. Family clustering was also observed in three patterns: familial combined hyperlipidemia, hypertriglyceridemia, and dysbetalipoproteinemia. Very high TGs ( $\geq 5.65 \mathrm{mmol} / \mathrm{L})$ are typically denoted as catabolic defects of TRL, also attributed to both acquired and genetic factors. However, genetic factors may play a more dominant role because overt genetic alterations are frequently observed in this classification. Genetic defects in LPL, glycosyl-phosphatidyl-inositol anchored high-density lipoprotein binding protein 1 (GPIHBP1) or ApoC2, and the excessive expression of $\mathrm{ApoC} 3$, angiopoietin-related protein (Angptl) 3, and Angpt/4 are known to induce severe hypertriglyceridemia. ${ }^{15,21}$

\section{Triglycerides and ischemic stroke}

\section{Effects of triglycerides on the risk of ischemic stroke}

The relationship between TGs and ischemic stroke has been widely studied in the recent decades (Table 2). ${ }^{8,13,22,23}$ Ample evidence has shown that hypertriglyceridemia is a risk factor for ischemic stroke, although this evidence has not been confirmed. In a prospective cohort study covering 267,500 Chinese individuals with an average follow-up period of 6 to 19 years, investigators found that for every $1 \mathrm{mmol} / \mathrm{L}$ increase in TG levels, the multifactorial adjusted hazard ratio (HR) and 95\% confidence interval $(\mathrm{Cl})$ for ischemic stroke was $1.07(95 \% \mathrm{Cl}, 1.05$ to 1.09$).{ }^{24}$ In a meta-analysis of risk factors for ischemic stroke in Asians, the researchers evaluated 2,611 patients diagnosed with ischemic stroke and 2,833 controls. Using a random-effects model, hypertriglyceridemia was observed to be significantly associated with ischemic stroke $(P=0.007) .{ }^{25}$ In a pro- 
Table 1. Stratification of fasting triglycerides by NCEP-ATPIII ${ }^{18}$

\begin{tabular}{|c|c|c|}
\hline Classification of serum triglycerides & Causes of elevated serum triglycerides & Clinical significance \\
\hline \multicolumn{3}{|l|}{ Normal triglycerides $(1.7 \mathrm{mmol} / \mathrm{L})$} \\
\hline $\begin{array}{l}\text { Borderline high triglycerides } \\
(1.7-2.25 \mathrm{mmol} / \mathrm{L})\end{array}$ & $\begin{array}{l}\text { Acquired causes } \\
\text { Overweight and obesity } \\
\text { Physical inactivity } \\
\text { Cigarette smoking } \\
\text { Excess alcohol intake } \\
\text { High carbohydrate intake (>60\% of total energy) } \\
\text { Secondary causes* } \\
\text { Genetic causes } \\
\text { Various genetic polymorphism }\end{array}$ & $\begin{array}{l}\text { Marker for atherogenic dyslipidemia } \\
\text { Elevated small LDL particles } \\
\text { Low HDL cholesterol } \\
\text { Marker for the metabolic syndrome } \\
\text { Elevated blood pressure } \\
\text { Insulin resistance and glucose intolerance } \\
\text { Prothrombotic state } \\
\text { Proinflammatory state }\end{array}$ \\
\hline High triglycerides (2.26-5.64 mmol/L) & $\begin{array}{l}\text { Acquired causes } \\
\text { Same as for borderline high triglycerides (usually } \\
\text { combined with foregoing causes) } \\
\text { Secondary causes* } \\
\text { Genetic patterns } \\
\text { Familial combined hyperlipidemia } \\
\text { Familial hypertriglyceridemia } \\
\text { Polygenic hypertriglyceridemia } \\
\text { Familial dysbetalipoproteinemia }\end{array}$ & $\begin{array}{l}\text { Elevated atherogenic remnant lipoproteins } \\
\text { Marker for other components of atherogenic dyslipidemia } \\
\text { (see above) } \\
\text { Marker for the metabolic syndrome (see above) }\end{array}$ \\
\hline Very high triglycerides ( $\geq 5.65 \mathrm{mmol} / \mathrm{L})$ & $\begin{array}{l}\text { Usually combined causes } \\
\text { Same as for high triglycerides } \\
\text { Familial lipoprotein lipase deficiency } \\
\text { Familial apolipoprotein C-II deficiency }\end{array}$ & $\begin{array}{l}\text { Metabolic syndrome, type } 2 \text { diabetes, and increased risk for CHD } \\
\text { common } \\
\text { Increased risk for acute pancreatitis (risk proportional to } \\
\text { triglyceride elevation above } 1,000 \mathrm{mg} / \mathrm{dL} \text { ) } \\
\text { Chylomicronemia syndrome (triglycerides }>2,000 \mathrm{mg} / \mathrm{dL} \text { ) } \\
\text { Eruptive skin xanthomas } \\
\text { Hepatic steatosis } \\
\text { Lipemia retinalis } \\
\text { Mental changes } \\
\text { High risk for pancreatitis }\end{array}$ \\
\hline
\end{tabular}

NCEP-ATPIII, Third Report of the National Cholesterol Education Program-Expert Panel on Detection, Evaluation, and Treatment of High Blood Cholesterol in Adults; LDL, low-density lipoprotein; HDL, high-density lipoprotein; CHD, coronary heart disease.

*Secondary causes of elevated triglycerides: diabetes mellitus, chronic renal failure, nephrotic syndrome, Cushing's disease, lipodystrophy, pregnancy, and various drugs (corticosteroids, beta-blockers, retinoids, oral estrogens [not transcutaneous estrogen], tomoxifen, protease inhibitors for acquired immunodeficiency syndrome).

spective cohort study involving 42,005 volunteers aged 20 to 80 years with an average follow-up period of 3.6 years, the researchers found that after adjusting for age, body mass index (BMI), systolic blood pressure (SBP), diastolic blood pressure, cigarette smoking, alcohol consumption, use of lipid-lowering drugs, diabetes, history of hypertension, family history of cardiovascular disease, and other confounding factors, whether in men or women, high TG levels were associated with an increased risk of ischemic stroke (men: adjusted HR, 1.06; 95\% $\mathrm{Cl}, 1.00$ to 1.12 and women: adjusted $\mathrm{HR}, 1.12 ; 95 \% \mathrm{Cl}, 1.01$ to 1.23); additionally, this association was more notable among women. ${ }^{26}$ In another nested case-control study, 5,475 ischemic stroke cases, 4,776 intracerebral hemorrhage cases, and 6,290 common control subjects without prior history of cardiovascular disease, cancer, or lipid-lowering, anticoagulant, or antiplatelet treatment at baseline were enrolled. The results demonstrated that plasma TG concentrations were weakly correlated with ischemic stroke risk (relative risk [RR], 1.02; 95\%
$\mathrm{Cl}, 1.00$ to 1.04 per $30 \%$ higher TGs). ${ }^{8}$ In a retrospective study, researchers used the Optum Research Database; additionally, through multiple screening and multivariate analyses, they showed that patients with hypertriglyceridemia had a significantly increased risk of nonfatal stroke $(\mathrm{HR}, 1.27 ; 95 \% \mathrm{Cl}, 1.14$ to $1.42 ; P<0.001) .{ }^{27}$

In patients with diabetes, lower TGs seem to be protective factors for stroke. In one study, using Tukey's multiple comparison, researchers found that higher TG levels were significantly associated with an increased risk of small-vessel occlusion, a subtype of ischemic stroke, in diabetes mellitus patients $(P=0.013){ }^{28}$ In a community-based, prospective cohort of American Indians (median follow-up 17.7 years), researchers studied 3,216 participants (40\% men, $41 \%$ with diabetes), who had no cardiovascular disease at baseline. In patients with diabetes, hypertriglyceridemia plus low HDL-C levels were associated with a 2.13-fold greater $\mathrm{HR}$ and $95 \% \mathrm{Cl}$ (1.06 to 4.29) for stroke $(P=0.060)$ when compared with those in individuals with 
Table 2. Effects of triglycerides on the risk of ischemic stroke

\begin{tabular}{|c|c|c|c|c|c|c|}
\hline Study & Design & Race & No. of cases & Characteristic & $\mathrm{OR}, \mathrm{RR}$, or HR $(95 \% \mathrm{Cl})$ & $P$ \\
\hline Gu et al. $(2019)^{24}$ & $\begin{array}{l}\text { Prospective } \\
\text { cohort study }\end{array}$ & Chinese & 267,500 & Ischemic stroke, aged $\geq 20$ years old & $\begin{array}{l}\mathrm{HR}, 1.07(1.05-1.09) \text { for } \\
\text { every } 1 \mathrm{mmol} / \mathrm{L} \text { increase }\end{array}$ & \\
\hline Cui et al. $(2019)^{25}$ & Meta-analysis & Asian & 5,444 & $\begin{array}{l}\text { Ischemic stroke, eight articles, } 2,611 \text { confirmed } \\
\text { ischemic stroke patients and 2,833 healthy } \\
\text { controls aged from 51.3-70 years old }\end{array}$ & & 0.007 \\
\hline Liu et al. $(2019)^{26}$ & $\begin{array}{l}\text { Prospective } \\
\text { cohort study }\end{array}$ & Chinese & 42,005 & $\begin{array}{l}\text { Ischemic stroke, } 25,989 \text { men aged } 41.83 \pm 12.3 \\
\text { (mean } \pm S D \text { ) and } 16,016 \text { women aged } \\
43.02 \pm 13.17 \text { years old }\end{array}$ & $\begin{array}{l}\text { HR, men } 1.06(1.00- \\
1.12), \text { women } 1.12 \\
(1.01-1.23)\end{array}$ & \\
\hline Sun et al. $(2019)^{8}$ & $\begin{array}{l}\text { Nested case- } \\
\text { control study }\end{array}$ & Chinese & 16,541 & $\begin{array}{l}\text { Ischemic stroke, } 5,475 \text { ischemic stroke cases } \\
\text { ( } 53.1 \% \text { women) aged } 54.3 \pm 10.7 \text { years old } \\
\text { (mean } \pm \text { SD), } 4,776 \text { intracerebral hemorrhage } \\
\text { cases }(47.8 \% \text { women) aged } 58.8 \pm 10.7 \text { years } \\
\text { old (mean } \pm S D \text { ) and } 6,290 \text { control }(47.9 \% \\
\text { women) aged } 56.7 \pm 11.9 \text { years old (mean } \pm S D \text { ) }\end{array}$ & $\begin{array}{l}\text { RR, } 1.02(1.00-1.04) \\
\text { per } 30 \% \text { higher TGs }\end{array}$ & \\
\hline Toth et al. $(2018)^{27}$ & $\begin{array}{l}\text { Retrospective } \\
\text { study }\end{array}$ & American & 45,917 & $\begin{array}{l}\text { Nonfatal stroke, patients with diabetes or } \\
\text { atherosclerotic cardiovascular disease and } \\
\text { taking stain, 13,411 high TGs patients (TGs } \\
2.26-5.64 \mathrm{mmo} / \mathrm{L} \text { ) and } 32,506 \text { comparators } \\
\text { (TGs }<1.69 \mathrm{mmol} / \mathrm{L} \text { and } \mathrm{HDL}-\mathrm{C}>1.04 \mathrm{mmol} / \mathrm{L} \text { ) }\end{array}$ & $\mathrm{HR}, 1.27(1.14-1.42)$ & $<0.001$ \\
\hline Shin et al. $(2015)^{28}$ & & Korean & 1,438 & $\begin{array}{l}\text { 1,438 ( } 57 \% \text { men) Patients with acute ischemic } \\
\text { stroke and with } 67.6 \text { years old on average, } \\
\text { small-vessel occlusion, } 49.9 \% \text { with diabetes } \\
\text { mellitus }\end{array}$ & & 0.013 \\
\hline Lee et al. $(2017)^{23}$ & $\begin{array}{l}\text { Community- } \\
\text { based, } \\
\text { prospective } \\
\text { cohort study }\end{array}$ & $\begin{array}{l}\text { American } \\
\text { Indians }\end{array}$ & 3,216 & $\begin{array}{l}40 \% \text { Men, } 41 \% \text { with diabetes, median follow- } \\
\text { up } 17.7 \text { years, hypertriglyceridemia ( } 1.69 \\
\mathrm{mmol} / \mathrm{L} \text { ) plus low } \mathrm{HDL}-\mathrm{C} \text { levels }(<1.04 \mathrm{mmol} / \mathrm{L} \\
\text { for men, }<1.29 \mathrm{mmol} / \mathrm{L} \text { for women), stroke }\end{array}$ & & 0.060 \\
\hline Nichols et al. (2019) ${ }^{29}$ & & American & 27,953 & $\begin{array}{l}\text { Diabetic patients with LDL-C controlled by } \\
\text { statins, without other lipid-lowering } \\
\text { therapies, nonfatal stroke }\end{array}$ & $\mathrm{RR}, 1.23(1.01-1.49)$ & 0.037 \\
\hline \multirow[t]{2}{*}{ Ren et al. $(2018)^{30}$} & $\begin{array}{l}\text { Cross-sectional } \\
\text { study }\end{array}$ & Chinese & 223,612 & $\begin{array}{l}\text { T2DM patients, } 53.77 \% \text { men, aged } \\
58.31 \pm 11.39 \text { years, nonfatal stroke }\end{array}$ & $\begin{array}{l}\mathrm{OR}, 0.95(0.90-1.00) \\
(<15 \text { years })\end{array}$ & 0.054 \\
\hline & & & & & $\begin{array}{l}\mathrm{OR}, 1.58(1.45-1.72) \\
(\geq 15 \text { years })\end{array}$ & $<0.001$ \\
\hline Sultan et al. $(2018)^{31}$ & $\begin{array}{l}\text { Cross-sectional } \\
\text { study }\end{array}$ & Global & 482 & $\begin{array}{l}\text { Children with arterial ischemic stroke, } 59.8 \% \\
\text { were men, median age at stroke was } 6.1\end{array}$ & & \\
\hline Lee et al. $(2020)^{32}$ & $\begin{array}{l}\text { National cohort } \\
\text { study }\end{array}$ & Global & $5,680,055$ & $\begin{array}{l}\text { Statin-naive, aged } 20-39 \text { years old (mean age } \\
30.3 \text { years, } 60.8 \% \text { men), stroke }\end{array}$ & & $<0.001$ \\
\hline Huang et al. $(2020)^{33}$ & $\begin{array}{l}\text { Retrospective } \\
\text { study }\end{array}$ & Chinese & 3,249 & $\begin{array}{l}\text { Elderly hypertensive patients (systolic blood } \\
\text { pressure } \geq 140 \mathrm{~mm} \mathrm{Hg} \text { and/or diastolic blood } \\
\text { pressure } \geq 90 \mathrm{~mm} \mathrm{Hg} \text { or receiving } \\
\text { antihypertensive therapies), 1,455 male and } \\
1,794 \text { female, aged } 71.36 \pm 7.18 \text { years old } \\
\text { (mean } \pm \text { SD), ischemic stroke }\end{array}$ & & 0.002 \\
\hline Wang et al. $(2018)^{34}$ & Prospective study & Chinese & 4,081 & $\begin{array}{l}\text { 1,657 Men and 2,424 women, aged over } 35 \\
\text { ischemic stroke }\end{array}$ & HR, 1.71 (1.05-2.78) & \\
\hline Saeed et al. $(2018)^{35}$ & $\begin{array}{l}\text { Atherosclerosis } \\
\text { Risk In } \\
\text { Communities } \\
\text { study }\end{array}$ & American & 9,334 & $\begin{array}{l}\text { 5,527 Women and 3,807 men, LDL-TG, } \\
\text { ischemic stroke }\end{array}$ & $\begin{array}{l}\mathrm{HR}, 1.47(1.13-1.92) \\
(\mathrm{LDL}-\mathrm{TG})\end{array}$ & $<0.005$ \\
\hline Brola et al. $(2015)^{22}$ & & Poles & 1,284 & $\begin{array}{l}672 \text { Ischemic stroke patients and } 612 \text { control, } \\
\text { metabolic syndrome, hypertriglyceridemia }\end{array}$ & OR, 4.35 (2.78-9.43) & $<0.001$ \\
\hline Nichols et al. (2018) & $\begin{array}{l}\text { Longitudinal } \\
\text { observational } \\
\text { cohort study }\end{array}$ & American & 17,183 & $\begin{array}{l}\text { Receiving conventional statin only, nonfatal } \\
\text { stroke }\end{array}$ & $H R, 1.09$ (0.89-1.33) & 0.42 \\
\hline
\end{tabular}


Table 2. Continued

\begin{tabular}{|c|c|c|c|c|c|c|}
\hline Study & Design & Race & No. of cases & Characteristic & $\mathrm{OR}, \mathrm{RR}$, or $\mathrm{HR}(95 \% \mathrm{Cl})$ & $P$ \\
\hline \multirow[t]{2}{*}{ Toth et al. (2019) } & \multirow{2}{*}{$\begin{array}{l}\text { Retrospective } \\
\text { study }\end{array}$} & \multirow[t]{2}{*}{ Global } & \multirow[t]{2}{*}{59,977} & \multirow{2}{*}{$\begin{array}{l}\text { Taking statins, aged more than } 45 \text { years (62 on } \\
\text { average, } 49 \% \text { women), with diabetes and/or } \\
\text { atherosclerotic cardiovascular disease, } \\
\text { nonfatal stroke }\end{array}$} & $H R, 1.14(1.04-1.24)$ & 0.004 \\
\hline & & & & & $\begin{array}{l}\text { HR, } 1.08 \text { (0.98-1.19) } \\
\text { (removing HDL-C and } \\
\text { other factors) }\end{array}$ & 0.12 \\
\hline \multirow[t]{2}{*}{ Wang et al. $(2020)^{41}$} & \multirow[t]{2}{*}{$\begin{array}{l}\text { Prospective } \\
\text { cohort study }\end{array}$} & \multirow[t]{2}{*}{ Chinese } & \multirow[t]{2}{*}{51,620} & \multirow[t]{2}{*}{$\begin{array}{l}75.95 \% \text { Men, aged } 52.79 \pm 11.80 \text { years old } \\
\text { (mean } \pm \text { SD), ischemic stroke }\end{array}$} & $\begin{array}{l}\text { Per SD increase } 0.99 \\
(0.92-1.06) \\
\text { (multivariate analysis) }\end{array}$ & 0.129 \\
\hline & & & & & $\begin{array}{l}\text { Per SD increase } 1.00 \\
\text { (0.93-1.06) (sensitivity } \\
\text { analyses) }\end{array}$ & 0.181 \\
\hline Kivioja et al. (2018) ${ }^{42}$ & $\begin{array}{l}\text { Population-based } \\
\text { cohort study }\end{array}$ & Finn & 2,364 & $\begin{array}{l}961 \text { Patients (603 men) and 1,403 control } \\
\text { ( } 793 \text { men), aged } 25-49 \text { years old, ischemic } \\
\text { stroke }\end{array}$ & $\begin{array}{l}\text { Adjusted OR, } 1.19 \\
(0.94-1.53)\end{array}$ & \\
\hline Bansal et al. $(2007)^{43}$ & Prospective study & American & 26,509 & $\begin{array}{l}\text { Women, 20,118 fasting and 6,391 nonfasting } \\
\text { TGs, cardiovascular events (including ischemic } \\
\text { stroke) }\end{array}$ & $H R, 4.48(1.98-10.15)$ & $<0.001$ \\
\hline $\begin{array}{l}\text { Freiberg et al. } \\
(2008)^{44}\end{array}$ & $\begin{array}{l}\text { Prospective, } \\
\text { population- } \\
\text { based cohort } \\
\text { study }\end{array}$ & Danes & 13,956 & Aged $20-80$ years old, ischemic stroke & $\begin{array}{l}\mathrm{HR}, 2.5(1.30-4.80) \\
\text { (men) and } 3.8(1.30-11) \\
\text { (women) }\end{array}$ & \\
\hline \multirow[t]{4}{*}{ Iso et al. $(2014)^{46}$} & \multirow{4}{*}{$\begin{array}{l}\text { Circulatory Risk in } \\
\text { Communities } \\
\text { Study }\end{array}$} & \multirow[t]{4}{*}{ Japanese } & \multirow[t]{4}{*}{10,659} & \multirow{4}{*}{$\begin{array}{l}\text { 4,264 Men and 6,395 women, aged from } 40 \text { to } \\
69 \text { years, } 2,424 \text { fasting ( } \geq 8 \text { hours after meal) } \\
\text { and } 8,235 \text { nonfasting ( }<8 \text { hours after meal), } \\
\text { ischemic stroke }\end{array}$} & $\begin{array}{l}\mathrm{HR}, 1.39 \text { (1.24-1.57) } \\
\text { (women, nonfasting TG) }\end{array}$ & 0.013 \\
\hline & & & & & $\begin{array}{l}\mathrm{HR}, 0.90(0.68-1.19) \\
\text { (women, fasting TG } \\
\text { level) }\end{array}$ & 0.887 \\
\hline & & & & & $\begin{array}{l}\mathrm{HR}, 1.04 \text { (0.94-1.15) } \\
\text { (men, nonfasting TG) }\end{array}$ & 0.219 \\
\hline & & & & & $\begin{array}{l}\mathrm{HR}, 1.10 \text { (0.94-1.30) } \\
\text { (men, fasting TG level) }\end{array}$ & 0.074 \\
\hline
\end{tabular}

$\mathrm{OR}$, odds ratio; $\mathrm{RR}$, relative risk; $\mathrm{HR}$, hazard ratio; $\mathrm{Cl}$, confidence interval; $\mathrm{SD}$, standard deviation; $\mathrm{TG}$, triglyceride; HDL-C, high-density lipoprotein cholesterol; LDL-C, low-density lipoprotein cholesterol; T2DM, type 2 diabetes mellitus.

normal blood glucose. ${ }^{23}$ In diabetic patients with LDL-C controlled by statins, the researchers divided the patients into a high TG group (2.26 to $5.54 \mathrm{mmol} / \mathrm{L}, \mathrm{n}=5,542)$ and a normal TG group $(<1.70 \mathrm{mmol} / \mathrm{L}, \mathrm{n}=22,411)$. After adjusting for age, sex, race/ethnicity, smoking status, blood pressure, hemoglobin A1C, serum creatinine, presence of ischemic heart disease, study site, and other influencing factors, a multivariate analysis showed that the high TG group (2.26 to $5.54 \mathrm{mmol} / \mathrm{L}$ ) had an increased nonfatal stroke incidence-by 23\% (RR, 1.23; 95\% $\mathrm{Cl}, 1.01$ to $1.49 ; P=0.037)$-when compared with the normal TG group. ${ }^{29}$ In a cross-sectional study of 223,612 type 2 diabetes mellitus patients, a multivariate analysis showed that low TGs $(<1.70 \mathrm{mmol} / \mathrm{L})$ were associated with a reduced risk of nonfatal stroke in patients who suffered from diabetes for no more than 15 years (odds ratio [OR], $0.95 ; 95 \% \mathrm{Cl}, 0.90$ to 1.00 ; $P=0.0504)$. However, in individuals with diabetes aged $\geq 15$ years, low TG levels were significantly associated with an increased risk of nonfatal stroke $(\mathrm{OR}, 1.58 ; 95 \% \mathrm{Cl}, 1.45$ to 1.72 ;

\section{$P<0.001) .^{30}$}

Moreover, hypertriglyceridemia is a risk factor for stroke irrespective of age. In a cross-sectional study on acute ischemic stroke (AIS) in children, hypertriglyceridemia was more common in children with arterial ischemic stroke than in those without stroke. ${ }^{31}$ In a national cohort study of 5,680,055 participants aged 20 to 39 years who had not taken statins, the results revealed that increased TG levels were associated with a higher risk of stroke $(P<0.001))^{32}$ After adjusting for common risk factors, TG levels were still an independent predictor of cardiovascular events (death, myocardial infarction, and stroke) (adjusted HR, 1.20; 95\% Cl, 1.14 to $1.26 ; P<0.001$ ). ${ }^{32}$ In a retrospective study, Huang et al. ${ }^{33}$ explored the relationship between TGs and the first ischemic stroke in elderly hypertensive patients in a Chinese community. From January 2010 to December 2011, 3,249 elderly hypertensive patients were recruited, including 1,455 men and 1,794 women, with an average age of $71.36 \pm 7.18$ years and an average follow-up period of 
5.5 years. A multivariate Cox regression analysis revealed that elevated TG levels were significantly associated with an increased risk of first ischemic stroke ( $P=0.002$ for trend) after adjusting for various confounding factors, such as sex, age, $\mathrm{BMI}, \mathrm{SBP}$, and fasting blood glucose. ${ }^{33}$

In certain cases, hypertriglyceridemia is a significant risk factor for stroke. In a prospective study conducted in a rural population in southern China, 4,081 participants aged 35 to 75 years with no history of stroke had an average of 5.6 years of follow-up, and the results revealed that the hypertriglyceridemic waist phenotype (a waist circumference $[\mathrm{WC}] \geq 90 \mathrm{~cm}$ and TG level $\geq 2.00 \mathrm{mmol} / \mathrm{L}$ for men or a $W C \geq 85 \mathrm{~cm}$ and TG levels $\geq 1.50 \mathrm{mmol} / \mathrm{L}$ for women) was significantly associated with an increased risk of ischemic stroke $(\mathrm{HR}, 1.71 ; 95 \% \mathrm{Cl}, 1.05$ to 2.78), after adjusting for confounding factors (i.e., age, sex, smoking status, drinking status, history of diabetes mellitus, history of hypertension, total cholesterol level, HDL-C level, and LDL-C level). ${ }^{34}$ In an Atherosclerosis Risk In Communities study, the fasting plasma remnant-like particle cholesterol (RLP-C) and TGs in low-density lipoprotein (LDL-TG) levels were measured in 9,334 participants without common cardiovascular diseases, and were followed up for 16 years to observe the incidence of cardiovascular events (coronary heart disease and ischemic stroke). The LDL-TG levels were correlated with TG levels $(r=0.64, P<0.0001)$; additionally, $L D L-T G$ was significantly associated with a higher risk of ischemic stroke after adjusting for age, sex, race, total cholesterol, HDL-C, SBP, antihypertensive medication use, current smoking, and diabetic status in both categorical and continuous analyses $\left(P<0.0001\right.$ and $H R_{1}$ $1.47 ; 95 \% \mathrm{Cl}, 1.13$ to $1.92 ; P<0.005$, respectively). ${ }^{35}$ Similarly, in a nested case-control study, researchers recruited 912 myocardial infarction, 1,146 ischemic stroke, 1,138 intracerebral hemorrhage cases, and 1,466 common control subjects. Nuclear magnetic resonance spectroscopy was used to measure 225 metabolic markers in baseline plasma samples. They found that TGs within most VLDL, small LDL, and small and medium HDL were positively associated with ischemic stroke. For intermediate-density lipoprotein (IDL), medium and large LDL, and very large HDL, no obvious association was observed. However, the TG concentrations were negatively correlated with ischemic stroke in large $\mathrm{HDL}(\mathrm{OR}, 0.89 ; 95 \% \mathrm{Cl}, 0.81$ to 0.98$) .{ }^{14}$ In a study evaluating the correlation between Polish AIS and metabolic syndrome, researchers included 672 patients (387 women and 285 men) aged 32 to 93 years. The stratified analysis showed that after adjusting for age, sex, and BMI, there was a significant association between hypertriglyceridemia and stroke in patients with metabolic syndrome (adjusted $\mathrm{OR}, 4.35 ; 95 \% \mathrm{Cl}$, 2.78 to $9.43 ; P<0.001){ }^{22}$ Moreover, genetic variants that pro- moted hypertriglyceridemia, such as the LPL S447X, LPL HindIII, and Apo A5 gene promoter region T-1131C polymorphisms, were associated with an increased risk of ischemic stroke. ${ }^{36-38}$

However, in patients receiving statin therapy, TG may not be a risk factor for stroke. In a longitudinal observational cohort study that evaluated the risk of hypertriglyceridemia and cardiovascular disease in patients receiving conventional statin control of LDL-C, after adjusting for age, sex, race/ethnicity, BMI, smoking status, blood pressure, diabetes, use of insulin, history of myocardial infarction, stroke or other ischemic heart disease, serum creatinine, study site, and other factors, a multivariate analysis showed that the incidence of nonfatal strokes in the high TG group was slightly higher than that in the normal TG group; however, there was no significant difference $(H R, 1.09 ; 95 \% \mathrm{Cl}, 0.89$ to $1.33 ; P=0.42){ }^{39}$ In a retrospective study that explored the correlation between elevated TGs and an increased cardiovascular risk, the researchers found that among individuals over 45 years of age taking statins, compared with the pre-matched comparator cohort (TG levels less than $1.70 \mathrm{mmol} / \mathrm{L}$ and HDL-C levels greater than $0.45 \mathrm{mmol} / \mathrm{L}$ ) ( $n=32,506$ patients), the risk of nonfatal strokes was significantly increased in the elevated TG cohort $(\geq 1.70 \mathrm{mmol} / \mathrm{L})$ ( $n=27,471$ patients) ( $\mathrm{HR}, 1.14 ; 95 \% \mathrm{Cl}, 1.04$ to $1.24 ; P=0.004)$. However, after removing HDL-C and other factors in the multivariate analysis model, no significant association was observed between TG levels and nonfatal strokes ( $\mathrm{HR}, 1.08 ; 95 \% \mathrm{Cl}, 0.98$ to $1.19 ; P=0.12)^{40}$

However, contradictory results exist regarding the relationship between TGs and ischemic strokes. In a prospective cohort study, 51,620 volunteers without a history of myocardial infarction, stroke, or cancer, who had undergone three health examinations between 2006 and 2010 were followed up for incident stroke occurrence. After adjusting for sex, age, mean TG level, use of lipid-lowering agents, education, income, smoking status, drinking status, physical activity, diabetes, hypertension, BMI, estimated glomerular filtration rate, and high-sensitivity C-reactive protein (CRP), multivariate analyses showed no significant association between TGs and ischemic stroke events (per standard deviation [SD] increase $0.99 ; 95 \% \mathrm{Cl}, 0.92$ to 1.06; $P=0.129) .^{41}$ The sensitivity analyses led to the same conclusion (per SD increase 1.00; 95\% Cl, 0.93 to 1.06; $P=0.181$ ). ${ }^{41}$ In a population-based cohort study investigating early-onset ischemic strokes, researchers included 961 patients with a first-ever ischemic stroke between 25 and 49 years of age and 1,403 frequency-matched stroke-free controls. A multivariate logistic regression analysis found that there was no significant association between high TGs and ischemic stroke (adjusted $\mathrm{OR}, 1.19 ; 95 \% \mathrm{Cl}, 0.94$ to 1.53$){ }^{42}$ 
Notably, a nonfasting TG level, rather than a fasting TG level, has been attracting more attention as a strong predictor of ischemic stroke. In a prospective study of 26,509 initially healthy women in the United States (20,118 fasting and 6,391 nonfasting) with a follow-up of a median of 11.4 years, nonfasting TGs, rather than fasting TGs, maintained a strong independent relationship with cardiovascular events, including ischemic stroke, in fully adjusted models (fully adjusted $H R$, 4.48; $95 \% \mathrm{Cl}, 1.98$ to $10.15 ; P<0.001$ for trend). ${ }^{43}$ One of the most remarkable studies on the relationship between nonfasting TGs and ischemic stroke is a prospective, population-based cohort study based on the Copenhagen City Heart Study (CCHS). ${ }^{44}$ This study included 13,956 participants, wherein the TG levels ranged from normal $(<1.00 \mathrm{mmol} / \mathrm{L})$ to very high $(\geq 5.00 \mathrm{mmol} / \mathrm{L})$, and had a follow-up of up to 31 years, during which 1,529 participants developed ischemic stroke. After a multivariate adjustment for the total cholesterol level, alcohol consumption, smoking, hypertension, atrial fibrillation, and lipid-lowering therapy, with further adjustment in women for postmenopausal status and hormone therapy, there was a 15\% increased risk $(95 \% \mathrm{Cl}, 0.09$ to 0.22$)$ of ischemic stroke for each $1.00 \mathrm{mmol} / \mathrm{L}$ increase in nonfasting TGs. After multivariate adjustment, the HRs for ischemic stroke among men and women with the highest nonfasting TGs $(5.00 \mathrm{mmol} / \mathrm{L}$ or greater) compared with those with the lowest level $(1.00 \mathrm{mmol} / \mathrm{L})$ were $2.5(95 \% \mathrm{Cl}, 1.30$ to 4.80$)$ and $3.8(95 \% \mathrm{Cl}, 1.30$ to 11$)$, respectively. As nonfasting TGs increased from $<1.00$ to $>5.00$ $\mathrm{mmol} / \mathrm{L}$, the incidence of ischemic stroke increased from $2.6 \%$ to $5.5 \%$ in men under 55 years old and from $1.9 \%$ to $4.0 \%$ in women. Among men and women over the age of 55 years, the incidence increased from $8.1 \%$ and $5.8 \%$ to $16.7 \%$ and $12.2 \%$, respectively. In the cross-sectional study included in the CCHS, men with a previous ischemic stroke versus controls had nonfasting TG levels of $2.16 \mathrm{mmol} / \mathrm{L}$ (interquartile range [IQR], $1.48-2.93)$ versus $1.67 \mathrm{mmol} / \mathrm{L}(\mathrm{IQR}, 1.18$ to 2.42$)(P<0.01)$; the corresponding values for women were $1.89 \mathrm{mmol} / \mathrm{L}(I \mathrm{QR}, 1.37$ to 2.59$)$ versus $1.44 \mathrm{mmol} / \mathrm{L}(\mathrm{IQR}, 1.02$ to 2.05$)(P<0.05){ }^{44} \mathrm{Sim}-$ ilar results were reported in 2011 when the CCHS reached a 33-year follow-up. ${ }^{45}$ Moreover, increasing cholesterol levels were not associated with the risk of ischemic stroke except in men with cholesterol levels $>9.00 \mathrm{mmol} / \mathrm{L}$ versus $<5.00 \mathrm{mmol} / \mathrm{L}$, with a HR of $4.40(95 \% \mathrm{Cl}, 1.90$ to 10.60$){ }^{45}$ In the Circulatory Risk in Communities Study, the researchers found that the nonfasting TG levels rather than the fasting TG levels could predict the risk of ischemic stroke in women (multivariable HR, 1.39; $95 \% \mathrm{Cl}$ per $1 \mathrm{mmol} / \mathrm{L}$ increment, 1.24 to $1.57 ; P$ for trend $=0.013$ vs. multivariable $\mathrm{HR}, 0.90 ; 95 \% \mathrm{Cl}$ per $1 \mathrm{mmol} / \mathrm{L}$ increment, 0.68 to $1.19 ; P$ for trend $=0.887$, respectively), while in men, neither could predict the risk of ischemic stroke (multivariable $\mathrm{HR}, 1.04 ; 95 \% \mathrm{Cl}$ per $1 \mathrm{mmol} / \mathrm{L}$ increment, 0.94 to 1.15; $P$ for trend $=0.219$ vs. multivariable $\mathrm{HR}, 1.10 ; 95 \% \mathrm{Cl}$ per $1 \mathrm{mmol} / \mathrm{L}$ increment, 0.94 to 1.30 ; $P$ for trend $=0.074$, respectively). ${ }^{46}$ Similarly, researchers found that nonfasting TGs could replace fasting TGs as a risk predictor of future cardiovascular events, including myocardial infarction, stroke, or cardiac death in Japanese diabetic patients. ${ }^{47}$

\section{Effects of triglycerides on the severity and prognosis of ischemic stroke}

Despite the association between elevated TGs and an increased risk of ischemic stroke, low serum TG levels do not necessarily benefit patients already suffering from acute stroke (Table 3). In a prospective study of 790 patients with AIS (men, 41.0\%, age $79.4 \pm 6.8$ years), the researchers found that the serum logTG levels in patients with moderate/severe stroke at admission were significantly lower than those in patients with mild stroke $(115 \pm 65$ vs. $120 \pm 51, P<0.05)$ and serum log-TG levels of patients who died during hospitalization were significantly lower than those of discharged patients $(P<0.001){ }^{48}$ In a binary logistic regression analysis, the serum log-TG levels were an independent predictor of moderate/severe stroke and nosocomial mortality at admission $(\mathrm{RR}, 0.24 ; 95 \% \mathrm{Cl}, 0.08$ to $0.68 ; P<0.01$ and $\mathrm{RR}, 0.09 ; 95 \% \mathrm{Cl}, 0.01$ to $0.87 ; P<0.05) .{ }^{48}$ Dziedzic et al. ${ }^{49}$ showed that patients with severe stroke on admission had significantly lower serum TG levels than patients with $\mathrm{mild} / \mathrm{mod}-$ erate stroke on admission $(1.04 \pm 0.60 \mathrm{mmol} / \mathrm{L}$ vs. $1.70 \pm 1.30$ $\mathrm{mmol} / \mathrm{L}$ ). Moreover, after adjusting for age, sex, atrial fibrillation, diabetes mellitus, obesity, and ischemic heart disease, patients with TGs $>2.30 \mathrm{mmol} / \mathrm{L}$ had a lower risk of severe stroke than those with TGs $\leq 2.30 \mathrm{mmol} / \mathrm{L}(\mathrm{OR}, 0.58 ; 95 \% \mathrm{Cl}, 0.35$ to $0.95){ }^{49}$ Similarly, an inverse relationship between National Institutes of Health Stroke Scale scores (NIHSS; with higher score meaning worse severity) and fasting TGs has been reported by several studies. ${ }^{50,51}$ Higher fasting TGs ( $\geq 1.70 \mathrm{mmol} / \mathrm{dL}$ ) within 24 hours after admission were also associated with a lower infarct volume on brain computed tomography $(P=0.014){ }^{52}$

Low TG levels may also have detrimental effects on long-term prognoses. In a study involving 1,464 patients with small artery occlusion, a subtype of ischemic stroke, the researchers found that elevated TG levels were a protective factor for death 36 months after stroke ( $\mathrm{RR}, 0.05 ; 95 \% \mathrm{Cl}, 0.00$ to 0.57$){ }^{53}$ In a prospective study of 1,310 nondiabetic acute stroke patients with a mean follow-up time in survivors of 1,195 days, lower fasting TG levels independently predicted higher mortality, whereas serum cholesterol levels were not an independent predictor. ${ }^{51}$ The relative hazard per additional quartile of TGs was $0.84(95 \% \mathrm{Cl}$, 
Table 3. Effects of triglycerides on the severity and prognosis of ischemic stroke

\begin{tabular}{|c|c|c|c|c|c|c|}
\hline Study & Design & Race & No. of cases & Characteristic & $\mathrm{OR}$, $\mathrm{RR}$, or $\mathrm{HR}(95 \% \mathrm{Cl})$ & $P$ \\
\hline \multirow[t]{3}{*}{ Tziomalos et al. $(2017)^{48}$} & \multirow[t]{3}{*}{ Prospective study } & \multirow[t]{3}{*}{ Greek } & \multirow[t]{3}{*}{790} & \multirow{3}{*}{$\begin{array}{l}41.0 \% \text { Men, aged } 79.4 \pm 6.8 \text { years } \\
\text { (mean } \pm \text { SD), prognosis of acute } \\
\text { ischemic stroke }\end{array}$} & & $<0.001$ \\
\hline & & & & & $\begin{array}{l}\mathrm{RR}, 0.24 \text { (0.08-0.68) } \\
\text { (moderate/severe stroke) }\end{array}$ & $<0.010$ \\
\hline & & & & & $\begin{array}{l}\mathrm{RR}, 0.09 \text { (0.01-0.87) } \\
\text { (in-hospital mortality) }\end{array}$ & $<0.050$ \\
\hline Dziedzic et al. (2004) ${ }^{49}$ & & Poles & 863 & $\begin{array}{l}863 \text { Patients ( } 422 \text { men) with } \\
\text { acute ischemic stroke, stroke } \\
\text { severity }\end{array}$ & $\mathrm{OR}, 0.58(0.35-0.95)$ & \\
\hline Pikija et al. (2006) ${ }^{52}$ & & Croatian & 121 & $\begin{array}{l}121 \text { (53 men, aged } 47-93 \text { years } \\
\text { old) acute ischemic stroke } \\
\text { patients, stroke severity }\end{array}$ & & 0.014 \\
\hline \multirow[t]{2}{*}{ Zhao et al. (2019) } & & Chinese & 1,464 & Small artery occlusion & $\mathrm{RR}, 0.05(0.00-0.57)$ & \\
\hline & & & & Recurrent stroke & $\mathrm{RR}, 2.32$ (1.10-4.89) & 0.027 \\
\hline Weir et al. $(2003)^{51}$ & Prospective study & British & 1,310 & $\begin{array}{l}\text { Nondiabetic acute stroke patients } \\
\text { (645 men) with median age of } \\
70 \text { years old, prognosis of acute } \\
\text { ischemic stroke }\end{array}$ & RR, 0.84 (0.77-0.91) & \\
\hline Ryu et al. $(2010)^{50}$ & $\begin{array}{l}\text { Prospective follow-up } \\
\text { study }\end{array}$ & Korean & 1,067 & $\begin{array}{l}\text { Primary acute ischemic stroke for } \\
5 \text { years, } 226 \text { cardioembolic } \\
\text { stroke patients and } 841 \text { non- } \\
\text { cardioembolic stroke patients, } \\
\text { stroke mortality }\end{array}$ & & $<0.001$ \\
\hline Celap et al. $(2019)^{59}$ & $\begin{array}{l}\text { Cross-sectional } \\
\text { observational study }\end{array}$ & Croatian & 250 & $\begin{array}{l}\text { Acute ischemic stroke, severity } \\
\text { and prognosis }\end{array}$ & $\mathrm{OR}, 0.75(0.43-1.30)$ & 0.306 \\
\hline Deng et al. (2019) ${ }^{58}$ & Meta-analysis & Global & 867 & $\begin{array}{l}\text { Acute ischemic stroke, early } \\
\text { neurological deterioration }\end{array}$ & OR, 5.31 (1.79-15.70) & \\
\hline \multirow[t]{2}{*}{ Xu et al. $(2014)^{60}$} & & Chinese & 1,568 & $\begin{array}{l}\text { 1,003 Men, acute ischemic } \\
\text { stroke, prognosis }\end{array}$ & $\begin{array}{l}\mathrm{OR}, 0.88 \text { (0.39-1.99) } \\
\text { (multivariate logistic } \\
\text { regression analysis) }\end{array}$ & \\
\hline & & & & & $\begin{array}{l}\mathrm{OR}, 1.12 \text { (0.54-2.32) } \\
\text { (propensity score- } \\
\text { adjusted analysis) }\end{array}$ & \\
\hline Li et al. $(2017)^{61}$ & $\begin{array}{c}\text { Meta-analysis of } \\
\text { cohort studies }\end{array}$ & Global & 7,752 & Recurrent stroke & RR, 1.04 (0.84-1.29) & \\
\hline
\end{tabular}

$\mathrm{OR}$, odds ratio; $\mathrm{RR}$, relative risk; $\mathrm{HR}$, hazard ratio; $\mathrm{Cl}$, confidence interval; $\mathrm{SD}$, standard deviation.

0.77 to 0.91$).^{51}$ Similarly, a recent study also showed that lower TG levels were related to higher all-death cause and vascular death rates in all patients and in the non-cardioembolic stroke group $(P<0.001$, both), but not in the cardioembolic stroke group. ${ }^{50}$ In a Cox regression analysis with multivariate adjustment, compared with the highest quartile, the adjusted HR of the lowest quartile for all-cause death was $2.58(95 \% \mathrm{Cl}, 1.38$ to 4.82$)$ and that for vascular death was $3.50(95 \% \mathrm{Cl}, 1.39$ to 8.82 ) in the non-cardioembolic stroke group. ${ }^{50}$

Notably, the effects of TGs on the early prognosis are more complex. Most studies have found that hypertriglyceridemia is a protective factor against ischemic strokes. A hospital-based retrospective study with 530 patients with ischemic stroke lasting less than 7 days investigated the relationship between metabolic syndrome and the short-term prognosis of ischemic stroke. After adjusting for age and sex, a multiple logistic regression model analysis showed that elevated TGs decreased the risk of poor functional outcome at 30 or 90 days. ${ }^{54}$ In a study evaluating the effect of TGs on the clinical outcome of patients with AIS after 3 months, the researchers included 1,006 AIS patients (median age 68.5 years; 58.2\% men) admitted to the hospital between 2011 and 2014, used the modified Rankin Scale (mRS) score at 3 months after the attack to define the clinical endpoint (excellent outcome, mRS 0-1; good outcome, mRS 0-2; and death, mRS 6), and found that the TG levels were positively correlated with excellent outcome $(P<0.001)$ and good outcome $(P<0.001)$, but were negatively correlated with death $(P<0.001)$ after adjusting for various confounding factors, based on the patient's blood TG level at admission. ${ }^{55}$ To evaluate the effect of the TG/HDL-C ratio on 
the mortality rate of AIS after 3 months, the researchers recruited 1,459 patients (median age, 68.5 years; men 58.5\%) from 2011 to 2017 and divided them into retrospective training and prospective test cohorts. Multivariate analysis found that elevated TG levels were associated with a decreased risk of the 3-month mortality rate $(\mathrm{HR}, 0.42 ; 95 \% \mathrm{Cl}, 0.26$ to 0.60 ; $P<0.001$ and $\mathrm{HR}, 0.47 ; 95 \% \mathrm{Cl}, 0.22$ to $0.73 ; P<0.001$, respectively) in both the training and test cohorts. ${ }^{56}$ In a retrospective study, Kang et al. ${ }^{57}$ enrolled 556 patients with ischemic stroke and tested their fasting and nonfasting TG levels on admission. A multivariate analysis showed that after adjusting for several confounding factors, including the use of statins after discharge, higher fasting TG levels and higher nonfasting TG levels were both significantly associated with good 3-month functional activity after AIS (OR, 2.93; 95\% Cl, 1.67 to 5.14 and $\mathrm{OR}, 2.66 ; 95 \% \mathrm{Cl}_{1} 1.51$ to 4.67 , respectively). ${ }^{57}$ In a meta-analysis, researchers included 21 full-text studies from the Cochrane Library, PubMed, and Web of Science databases. The results showed that the serum TG levels were significantly correlated with the death of AIS patients $(0 \mathrm{R}, 0.65 ; 95 \% \mathrm{Cl}, 0.43$ to 0.98$).{ }^{58} \mathrm{~A}$ subgroup analysis showed that both univariate analyses and multivariate analyses indicated that higher TG levels could reduce the mortality of AIS patients $(O R, 0.40$; $95 \% \mathrm{Cl}, 0.28$ to 0.57 and $\mathrm{OR}, 0.65 ; 95 \% \mathrm{Cl}, 0.43$ to 0.98$).{ }^{58}$

The effects of TGs on an early prognosis remain unclear. In a cross-sectional observational study, researchers recruited 250 participants with AIS and found that TGs were a protective factor for very severe stroke (NIHSS $\geq 21)\left(O R, 0.55 ; 95 \% \mathrm{Cl}_{\text {, }}\right.$ 0.34 to $0.91 ; P=0.019)$ through univariate regression analysis. However, after adjusting for age and sex, no significant association was observed in multivariate logistic regression analysis $(\mathrm{OR}, 0.75 ; 95 \% \mathrm{Cl}, 0.43$ to $1.30 ; P=0.306){ }^{59}$ In a meta-analysis, the summary of results from two studies indicated that TG levels were positively correlated with early neurological deterioration in patients with AIS (OR, 5.31; 95\% Cl, 1.79 to 15.70$){ }^{58}$ Researchers also found that elevated TG levels were an independent risk factor for relapse 3 months after stroke (RR, 2.32; $95 \% \mathrm{Cl}, 1.10$ to $4.89 ; P=0.027) .{ }^{53}$ In another study that aimed to uncover the relationship between dyslipidemia and the outcome (NIHSS >10 at discharge or death) of AIS, researchers included 1,568 patients with AIS from four hospitals from January 2006 to December 2008. Through a multivariate logistic regression analysis or propensity score-adjusted analysis, the results demonstrated that TG levels were not significantly associated with the outcome of AIS $(\mathrm{OR}, 0.88 ; 95 \% \mathrm{Cl}, 0.39$ to 1.99 and $\mathrm{OR}, 1.12 ; 95 \% \mathrm{Cl}, 0.54$ to 2.32 , respectively). ${ }^{60}$ In another meta-analysis of cohort studies that investigated the correlation between metabolic syndrome and stroke recur- rence, researchers found that patients with metabolic syndrome had a significantly increased risk of stroke recurrence (RR, 1.52; 95\% Cl, 1.17 to 1.97), although there was no obvious association between higher TG levels and stroke recurrence ( $R R, 1.04 ; 95 \% \mathrm{Cl}, 0.84$ to 1.29$).{ }^{61}$ In addition, in genetically modified hypertriglyceridemia mice (ApoCIII transgene or GPIHBP1 knockout), severe hypertriglyceridemia did not reduce ischemic brain damage. ${ }^{62}$ These results suggested that the role of hypertriglyceridemia in poor early outcomes, such as relapse and death, of ischemic stroke is still depressing.

Effects of triglyceride reduction on ischemic stroke Clinical trials assessing the efficacy of TG reduction in preventing ischemic strokes are limited and less convincing, mainly because of the lack of drugs targeting only TGs. The Veterans Affairs HDL Intervention Trial, a placebo-controlled, randomized trial conducted in 20 veteran affairs medical centers, studied the effects of gemfibrozil, a type of fibrate that increases HDL-C and reduces TGs in stroke prevention in men with coronary heart disease and low levels of both HDL-C and LDL-C (mean, 0.82 and $2.90 \mathrm{mmol} / \mathrm{L}$, respectively). ${ }^{63}$ After a follow-up of up to 5 years, 134 participants developed stroke, 76 in the placebo group, and 58 in the gemfibrozil group, with 90\% ischemic stroke. The adjusted RR reduction of gemfibrozil for stroke was 31\% (95\% Cl, 0.02 to 0.52$)$; additionally, the reduction in risk was evident after 6 to 12 months. ${ }^{63}$ This was the first trial that showed lipid therapy aimed at raising HDL cholesterol and lowering TGs reduced the stroke incidence. The results, however, could not yield the recommendation of gemfibrozil for prevention of stroke because of the specificity of participants, nor could it prove the statement that reducing TGs could prevent stroke as gemfibrozil raised HDL-C and lowered TGs simultaneously. In another multicenter, randomized, double-blind, placebo-controlled clinical trial that involved 8,179 patients, researchers found that in those patients who had elevated fasting TG levels (1.69 to $5.63 \mathrm{mmol} / \mathrm{L}$ ) and normal LDL-C levels ( 1.06 to $2.59 \mathrm{mmol} / \mathrm{L}$ ) and had been taking statins steadily for at least 4 weeks, using $2 \mathrm{~g}$ of icosapent ethyl twice daily could reduce their TG levels (median decrease of 18.3\% in the icosapent ethyl group vs. median increase of $2.2 \%$ in the placebo group) and significantly reduced the risk of ischemic events ( $\mathrm{HR}, 0.75 ; 95 \% \mathrm{Cl}, 0.68$ to $0.83 ; P<0.001)$ as well as nonfatal stroke (HR, $0.71 ; 95 \% \mathrm{Cl}, 0.54$ to 0.94$){ }^{64}$

To summarize, based on the current literature on the associations between TGs and stroke, it is highly likely that elevated TGs, especially nonfasting TGs, are a predictor of ischemic strokes. However, TGs may also exert protective effects during the occurrence, progression, and recovery of acute cerebral 


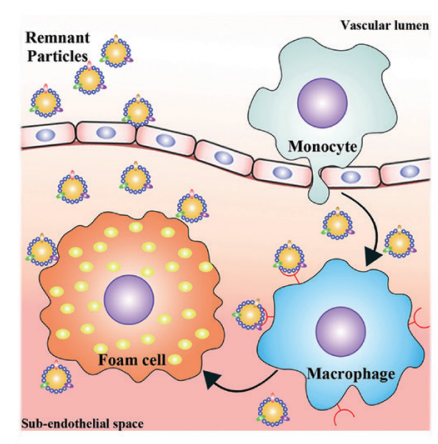

A
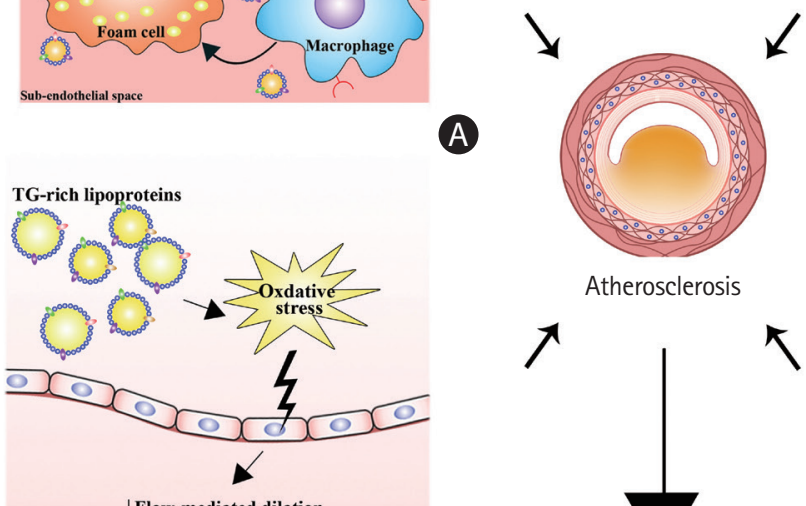

Atherosclerosis

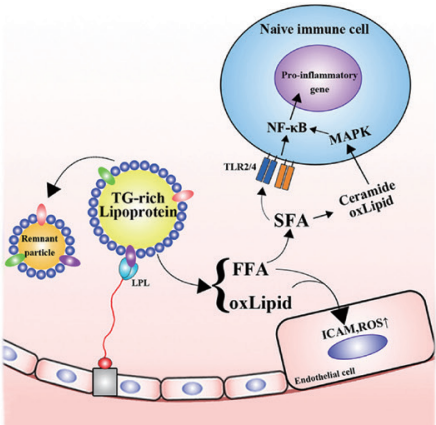

B

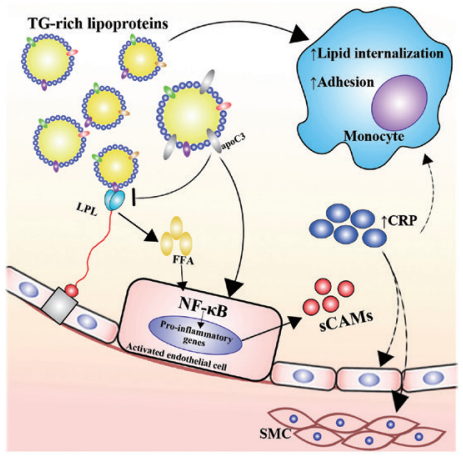

$\downarrow$ Ach-induced endothelium-dependent relaxation

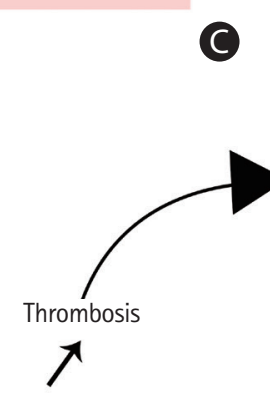

$\uparrow$ Concentration and activity of clotting factor VII, VIII, X

$\uparrow$ Expression and activity of PAI-1

$\uparrow$ Activation of platelets

$\uparrow$ Blood viscosity
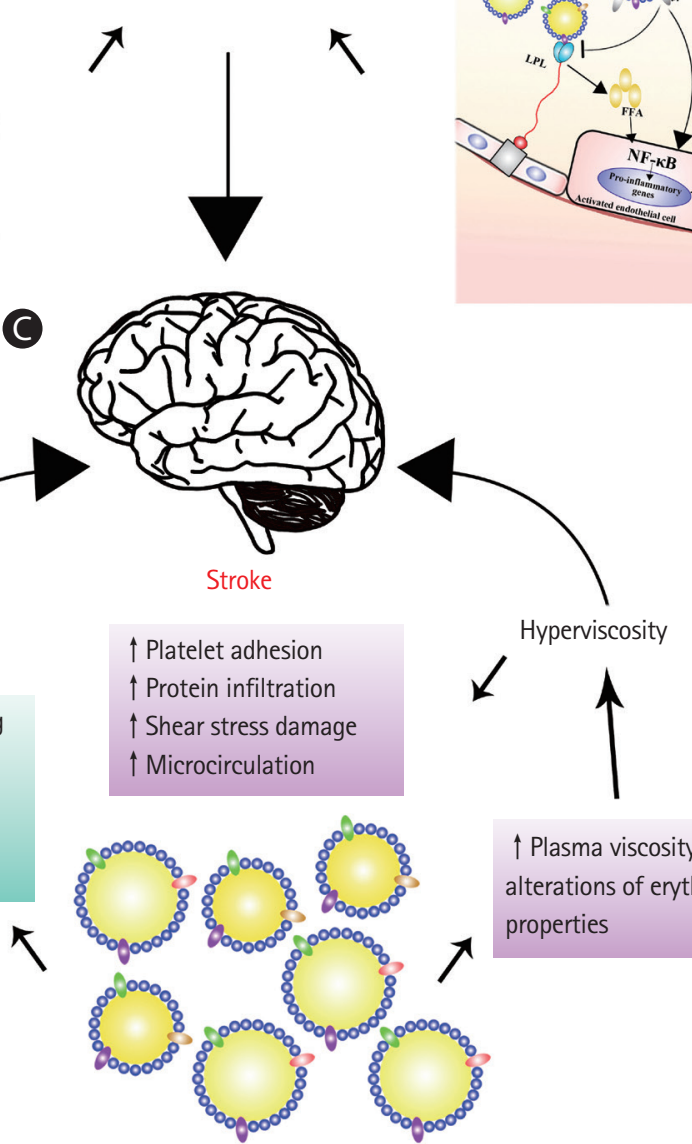

$\uparrow$ Plasma viscosity, alterations of erythrocyte properties

Hypertriglyceridemia

Figure 2. Mechanisms behind hypertriglyceridemia and ischemic stroke. Hypertriglyceridemia may increase the risk of ischemic stroke by predisposing patients to atherosclerosis, thrombosis, and hyperviscosity. Hypertriglyceridemia predisposes atherosclerosis mainly through the subendothelial deposition of remnant particles (A), toxic effects of triglyceride-rich lipoprotein (TRL) lipolytic products (B), impairment of endothelial function (C), and the establishment of local and systemic inflammation (D). Hypertriglyceridemia leads to increased concentrations and activity of clotting factors VII, VIII, X, and plasminogen activator inhibitor-1 (PAl-1), activation of platelets and higher blood viscosity, which together predict a higher risk of thrombosis. Hypertriglyceridemia represents a higher blood viscosity because of elevated plasma viscosity and altered erythrocyte properties. Hyperviscosity can increase platelet adhesion, protein infiltration to the subendothelial space, and shear stress damage, and impair microcirculation, leading to a higher risk of atherosclerosis, thrombosis, and cerebral ischemia. TG, triglyceride; NF-KB, nuclear factor KB; MAPK, mitogen-activated protein kinase; TLR, Toll-like receptor; SFA, saturated fatty acid; FFA, free fatty acid; oxLipid, oxidized phospholipid; ICAM, intracellular adhesion molecule; ROS, reactive oxygen species; LPL, lipoprotein lipase; CRP, C-reactive protein; sCAM, soluble cell adhesion molecule; SMC, smooth muscle cell. 
ischemia. The potential mechanisms behind these observations are reviewed in the next section.

\section{Mechanisms behind hypertriglyceridemia and ischemic stroke}

\section{Atherosclerosis}

Atherosclerosis is an underlying risk factor of ischemic stroke. Small plaques peeling off from unstable atherosclerotic plaques may embolize the intracranial arteries and cause artery-to-artery embolic stroke. ${ }^{65}$ Atherosclerosis occurring in certain crucial vessels may also produce an in situ thrombus and cause ischemic stroke. Notably, asymptomatic carotid stenosis has been recognized as a well-documented risk factor for stroke, and prophylactic carotid endarterectomy can decrease the risk. ${ }^{3}$

Despite lesser realization as an atherogenic factor than $L D L-C$, hypertriglyceridemia may promote the onset of ischemic stroke as it contributes to atherogenesis. There is a significant correlation between the carotid intima-media thickness and postprandial TG levels, implicating postprandial hypertriglyceridemia as an independent risk factor for early atherogenesis. $^{66,67}$ Theoretically, hypertriglyceridemia may lead to atherosclerosis via the following four mechanisms: subendothelial retention of remnant particles, toxic effects of lipolytic products, elicitation of endothelial dysfunction, and establishment of inflammation.

\section{Subendothelial retention of remnant particles}

Lipoproteins must enter the intima of arteries and be retained in the subendothelial space to cause atherosclerosis. ${ }^{68}$ Nascent CM and even VLDL seem to be excluded from the intima due to their large size. ${ }^{69}$ These factors might explain why the extremely high levels of TGs (>24.86 mmol/L), as seen in familial LPL deficiency with chylomicronemia syndrome, do not accelerate atherosclerosis. ${ }^{44}$ However, Daugherty et al. ${ }^{70}$ demonstrated the aortic accumulation of $\beta$-VLDL caused by diet-induced hypercholesterolemia in rabbits. Rapp et al. ${ }^{71}$ demonstrated that human atherosclerotic plaques contained intact TRLs. In addition, Proctor and $\mathrm{Mamo}^{72}$ demonstrated that small particles, such as $\mathrm{CM}$ remnants, could penetrate the arterial wall and were retained in the subendothelial space. Therefore, the remnant particles of CM and VLDL could penetrate into the intima of the arteries, become trapped, initiate inflammation, and trigger atherosclerosis, because they are smaller in size than $\mathrm{CM}$ and VLDL (Figure 2A) ${ }^{68,73}$ Furthermore, unlike LDL, remnant particles efflux very slowly from the intima, compared to their entry rate, and could be taken up directly by macrophages without modification ${ }_{1}^{74}$ favoring the formation of foam cells and atherosclerotic lesions. Therefore, this mechanism is the most simple explanation for the association between elevated nonfasting TG levels and an increased risk of ischemic stroke, as nonfasting TG levels are a parameter reflecting the level of TG-rich remnants. ${ }^{44,45}$ However, as TGs, but not cholesterol, could be degraded by macrophages in the intima, it might not be TGs but cholesterol inside the remnants that cause atherosclerosis. $^{44}$ There has been evidence demonstrating that high RLP-C levels are a significant and independent predictor of ischemic stroke events in patients with metabolic syndrome and mild carotid plaques. ${ }^{75}$ Moreover, although TG-rich particles in the intima still contain more TGs than cholesterol, the amount of cholesterol in each of these particles is 5 to 20 times greater than that in LDL. ${ }^{76}$ Therefore, the remnants have potential toxicities and proinflammatory activities on the vascular wall and can activate macrophages to secrete various cytokines, which may exacerbate the process of inflammation ${ }^{74}$ and eventually lead to atherogenesis and ischemic stroke.

\section{Toxic effects of lipolytic products}

In hypertriglyceridemia, LPL-mediated hydrolysis of TRLs may elevate the concentrations of free fatty acids (FFAs) in the proximity of the endothelium and in the systemic circulation, enhancing endothelial injury, inflammation, and atherosclerosis (Figure 2B). ${ }^{74,77}$ Lipolytic products from TRLs increase the endothelial permeability and induce apoptosis in human aortic endothelial cells (HAECs). ${ }^{78}$ Lipolysis of TRLs releases FFAs and oxidized lipids, such as oxidized phospholipids and 9- and 13-hydroxyocatadecadienoic acids (HODEs). The FFA fractions elicit proinflammatory responses and increase the expression of intracellular adhesion molecule (ICAM) and the production of reactive oxygen species (ROS) in HAECs. ${ }^{79}$ In particular, saturated fatty acids (SFAs) may activate Toll-like receptor 2 or 4 (TLR2 or TLR4) in naive immune cells, leading to the activation of nuclear factor $\mathrm{KB}(\mathrm{NF}-\mathrm{KB})$ and the subsequent transcription of proinflammatory genes. ${ }^{74}$ In addition, both oxidized phospholipids and ceramide produced from SFAs may activate the mitogen-activated protein kinase (MAPK) signaling pathway and enhance the transcriptional effectiveness of NF-KB. ${ }^{74} \mathrm{HODEs}$, especially $13-\mathrm{HODES}$, are potent inducers of ROS production in HAECs. ${ }^{79}$ HODEs lead to the synthesis of proinflammatory genes through NF-KB and/or other mechanisms. ${ }^{74}$ Furthermore, excessive intracellular ROS production may cause fatty acid peroxidation and result in the accumulation of peroxides and oxidative damage to mitochondria, which in turn exacerbate oxidative stress. ${ }^{80}$ Mitochondrial dysfunction can also result in vascular dysfunction and vascular cells apoptosis and favor the 
rupture of plaques and onset of stroke. Together, increased lipolytic products of TRLs in hypertriglyceridemia can increase the oxidative stress, cause endothelial injury, and elicit an inflammatory state, which may accelerate atherosclerosis and trigger ischemic stroke.

\section{Elicitation of endothelial dysfunction}

Endothelial dysfunction is considered an early feature of atherosclerosis. ${ }^{81}$ Hypertriglyceridemia, especially postprandial hypertriglyceridemia, has been shown to be associated with endothelial dysfunction in several studies (Figure 2C). Transient impairment of flow-mediated dilation (FMD) in the brachial artery has been observed in healthy subjects with transient hypertriglyceridemia induced by either intravenous or oral fat challenge. ${ }^{82,83}$ However, transient postprandial hypertriglyceridemia does not impair the endothelial function in forearm resistance vessels. ${ }^{84}$ Consistent results of impaired FMD and acetylcholine-induced endothelium-dependent relaxation have been reported in patients with hypertriglyceridemia. ${ }^{81,85,86}$ Reduction in serum TG levels via pharmacological therapy improved the endothelial function in obese subjects (men) and patients with coronary heart disease. ${ }^{86,87}$ Oxidative stress has been implicated as a result of postprandial hypertriglyceridemia and a cause of endothelial dysfunction. Increased leukocyte $\mathrm{O}_{2}^{-}$production is associated with elevated serum TGs and impaired FMD after a high-fat meal. ${ }^{88}$ Lipid-derived free radicals also have been observed to increase after a fat tolerance test, and the magnitude is greater in patients with type 2 diabetes than in healthy individuals. ${ }^{89}$ Remnants are also associated with endothelial cell apoptosis. High concentrations of CM remnants induce endothelial cell apoptosis. RLP induces apoptosis in endothelial cells by NAD(P)H oxidase-mediated superoxide and by cytokine production via lectin-like oxidized low-density lipoprotein receptor-1 (LOX-1). ${ }^{90}$ Collectively, hypertriglyceridemia can induce endothelial dysfunction, probably by increasing oxidative stress and inducing apoptosis, thus promoting atherosclerosis and ischemic strokes.

\section{Establishment of inflammation}

Hypertriglyceridemia may lead to a systemic inflammatory state via the activation of endothelial cells and leukocytes and elevation of CRP, thereby accelerating atherosclerosis (Figure 2D). The critical steps of inflammation in atherosclerosis involve the adhesion of monocytes to endothelial cells and their subsequent transmigration into the vascular wall. The plasma levels of soluble cell adhesion molecules (sCAMs) can reflect the degree of endothelial activation. ${ }^{91}$ Increased levels of soluble vascular cell adhesion molecule-1 (VCAM-1), ICAM-1, and
E-selectin, as well as leukocyte cell adhesion molecules CD18, CD49d, and CD54 are observed in patients with hypertriglyceridemia. ${ }^{91,92}$ Chronic low-dose lipid infusion in healthy individuals also leads to the induction of soluble ICAM-1, VCAM-1, and endothelin-1 (ET-1), which is independent of its insulin-desensitizing effects. ${ }^{93}$ Monocyte chemoattractant protein-1 (MCP1), a C-C chemokine, stimulates the migration of monocytes through arterial endothelial layers and is postulated to play a critical role in the development of atherosclerosis. ${ }^{94}$ Maeno et al..$^{95}$ reported that IDL can stimulate MCP-1 mRNA expression in cultured human umbilical vein endothelial cells (HUVECs). ${ }^{95}$ In addition, RLPs can induce MCP- 1 expression in HUVECs. ${ }^{96}$ Others have demonstrated that rat $\mathrm{CM}$ remnants strongly stimulate mRNA expression and protein secretion of MCP-1 in vascular smooth muscle cells by activating p38 MAPK. ${ }^{97}$ Prandial hypertriglyceridemia also transiently increases the lipid internalization of monocytes and their adhesion to VCAM-1 from healthy subjects fed a standardized high-fat meal. ${ }^{98}$ In addition, when cultured in the presence of RLPs, the adhesion of human monocytic U937 cells to HUVECs increased under physiological laminar flow conditions. ${ }^{99}$ These results favor the recruitment of monocytes during the development of atherosclerosis. Mechanistically, VLDL can activate NF-KB in endothelial cells, which is mediated by the release of VLDL fatty acids but not by the oxidation of VLDL. ${ }^{100}$ FFAs can also activate NF-KB in endothelial cells and regulate the TNF-a-induced activation of endothelial cells. ${ }^{100,101}$

Another potential mechanism linking hypertriglyceridemia to atherosclerosis is related to CRP. ${ }^{102}$ Elevated CRP levels also correlate with elevated TG levels and an increased risk of coronary heart disease; ${ }^{102,103}$ however, it remains unknown whether it is a causal factor in the pathogenesis. ${ }^{103,104}$ Nevertheless, a series of experimental studies indicated that CRP promotes atherothrombosis via the regulation of endothelial cells, alterations in the functions of vascular smooth muscle and monocytes/macrophages, changes in matrix biology, and the promotion of coagulation. ${ }^{105}$ In a rat model of middle cerebral artery occlusion, human CRP infusion could increase the infarct volume, indicating that human CRP contributes to ischemic tissue damage. ${ }^{106}$ Overall, the proinflammatory state elicited by hypertriglyceridemia may contribute to the pathogenesis of atherosclerosis and even alter the pathophysiology of ischemic stroke.

\section{Hyperviscosity and thrombosis}

Blood viscosity is closely associated with plasma viscosity and erythrocyte properties (i.e., erythrocyte concentration, volume, deformability, and aggregation), with the latter accounting for a 
larger part. ${ }^{107,108}$ An association between increased plasma TGs and elevated blood viscosity was reported previously. ${ }^{109,110}$ The most straightforward explanation for this phenomenon may be that the elevated plasma viscosity is caused by increased levels of lipoproteins, as the plasma viscosity is determined by the water content and macromolecular components. ${ }^{107,108}$ Indeed, in vitro studies have shown that isolated $\mathrm{CM}, \mathrm{VLDL}$, and $\mathrm{LDL}$ cause a dose-dependent and exponential rise in plasma viscosity, which is greater with larger lipoproteins. ${ }^{11,112}$ Moreover, in patients with metabolic syndromes, hypertriglyceridemia also independently predicts erythrocyte hyperaggregability. ${ }^{110}$ Consistently, an LPL-deficient mouse model with severe hypertriglyceridemia also displays an erythrocyte disturbance, which includes decreased deformability, electrophoresis rate, membrane fluidity, and increased osmotic fragility. ${ }^{109}$ Therefore, hypertriglyceridemia may additionally cause high blood viscosity via alterations of erythrocyte properties (Figure 2).

Blood viscosity and its determinants (i.e., plasma viscosity, fibrinogen, and hematocrit) are associated with carotid intima-media thickness, an early stage of atherosclerosis in the Edinburgh Artery Study. ${ }^{113}$ Additionally, in the same study, elevated blood viscosity, hematocrit, plasma viscosity, and fibrinogen were shown to correlate with stroke occurrence. ${ }^{114}$ In addition, worsened blood rheological properties were observed in patients with stroke, ${ }^{115}$ who showed enhanced whole blood viscosity due to the substantial increase in plasma viscosity and the impairment of microrheological blood properties-that is, elevated erythrocyte aggregability and decreased deformability compared with the healthy group. ${ }^{115}$

Elevated blood viscosity may promote atherosclerotic development by increasing the platelet adhesion to the sub-endothelium and protein infiltration into the arterial wall, and altering local shear forces at the sites of atherogenesis. ${ }^{113}$ Elevated plasma viscosity may also lead to atherothrombosis due to impaired microcirculatory flow, increased shear stress damage at the blood-endothelial interface, enhanced interactions of plasma protein with the endothelium in post-stenotic recirculation zones, and an increased propensity of thrombosis. ${ }^{116}$ In summary, hypertriglyceridemia may lead to the elevation of blood viscosity by increasing the plasma viscosity and causing erythrocyte disturbance, which can promote atherosclerosis, thrombosis, and cerebral ischemia, thus increasing the risk of ischemic stroke.

Thrombosis is a critical event in arterial diseases associated with ischemic stroke, ${ }_{1}^{117}$ as occlusion of intracranial arteries by either distant emboli (e.g., cardioemboli or carotid atherosclerotic plaques) or in situ thrombi can result in the onset of ischemic stroke. ${ }^{65}$ Hypertriglyceridemia may represent a procoagu- lant state and therefore contribute to the onset of ischemic stroke through its effects on thrombosis (Figure 2). ${ }^{102}$

Hypercoagulability and reduced fibrinolytic capacity are associated with hypertriglyceridemia and postprandial triglyceridemia. ${ }^{118-120}$ Elevations in the concentrations and activity of clotting factors VII, VIII, and X have been implicated in hypertriglyceridemia. ${ }^{118,121-123}$ In particular, Factor VII, an essential component in the extrinsic coagulant pathway, is closely associated with hypertriglyceridemia. ${ }^{121-124}$ Notably, the activity of FVII is an independent predictor of myocardial infarction in healthy middle-aged men with fatal coronary events. ${ }^{120}$ However, activation of the intrinsic pathway of coagulation does not contribute to the hemostatic imbalance in hypertriglyceridemia. ${ }^{125}$ In addition, the increased expression and activity of plasminogen activator inhibitor-1 (PAI-1) is correlated with an increase in plasma TGs. ${ }^{119,122,126,127}$ As PAl-1 is the major physiological inhibitor of plasminogen activators in the circulation and the principal inhibitor of the fibrinolytic system, ${ }^{120}$ the elevation of PAl-1 indicates a suppression of fibrinolytic capacity and thus a high risk of thrombosis. Notably, the dietary intake of unsaturated fatty acids, rather than SFAs, is more potent in elevating the concentrations and activity of FVII and PAI$1 .^{128,129}$ In addition, elevated tissue-type plasminogen activator and antithrombin-III have also been observed in patients with hypertriglyceridemia, ${ }^{123,126,127}$ which may be a protective mechanism against thrombotic events in these patients.

Regarding the molecular mechanisms of hypercoagulability and hypertriglyceridemia, FVII activation by TRL is dependent on LPL-mediated lipolysis. ${ }^{130}$ VLDL from normal or hyperlipidemic individuals can stimulate the secretion of PAI- 1 from HUVECs. ${ }^{131,132}$ VLDL also enhances the synthesis and release of PAI-1 in HepG2 cells, ${ }^{133}$ which occurs through the binding of VLDL particles to LDLRs on the cells. ${ }^{111,133} \mathrm{CM}$ remnants increased the production of PAI- 1 in endothelial cells via the MAPK pathway and redox system. ${ }^{134}$ Notably, inhibition of the renin-angiotensin system with angiotensin-converting enzyme inhibitors and angiotensin type 1 receptor blockers (ARBs) could reduce the production of PAl-1 by remnants in endothelial cells. ${ }^{134}$ In addition, patients with primary hypertriglyceridemia have an increased activation of platelets in vivo, ${ }^{135}$ which may be related to changes in the lipid composition of the platelet membranes, oxidative stress, and the potential activation effects of VLDL on platelets. ${ }^{135}$

In conclusion, hypertriglyceridemia may promote thrombosis and the onset of ischemic stroke through a procoagulant effect involved in the disturbance of both blood coagulation and fibrinolysis. ${ }^{120,136}$ Hyperviscosity may also contribute to hypercoagulability, which is discussed in the next section. 


\section{Protective role of triglycerides in acute ischemic} stroke

Although hypertriglyceridemia may increase the risk of ischemic stroke by promoting atherosclerosis, thrombosis, and hyperviscosity, low serum TGs also appear to be detrimental to patients with respect to the severity on admission and outcome after acute stroke. $^{49-52}$ These notable clinical findings raise the question of whether TGs are protective against cerebral ischemic injury. Although it remains unclear, several mechanisms may be considered. First, low serum TG levels may reflect the underlying poor nutritional status. ${ }^{49-51}$ Although malnutrition after stroke is a risk factor for poor outcomes, it could not explain the severity of stroke on admission. ${ }^{49}$ Additionally, the association between TG concentrations in plasma and stroke mortality is independent of albumin and hemoglobin, which are two parameters reflecting the nutritional status. ${ }^{50}$ These results imply that TGs might confer additional effects during and after stroke occurrence. Another plausible mechanism for the inverse correlation between TGs and stroke severity and outcomes focuses on the protective function of TGs. ${ }^{50}$ Cellular accumulation of excessive fatty acids in TG pools likely diverts these molecules from pathways that lead to cytotoxicity. Therefore, intracellular TGs may serve as a buffer against lipotoxicity. ${ }^{137}$ In this case, unsaturated fatty acids can exert a protective effect against lipotoxicity through the promotion of TG accumulation. Mitochondrial adaptations may be a third explanation. Livers from hypertriglyceridemic mice have a greater content of glycerolipids and an increased oxidation of FFAs in the mitochondria. However, mitochondria in hypertriglyceridemic livers have a high resting respiration rate but normal oxidative efficiency of phosphorylation, reducing the generation of ROS and maintaining a normal metabolic phenotype; therefore, mitochondria do not develop insulin resistance. ${ }^{138}$ The brain contains high concentrations of polyunsaturated fatty acids that are susceptible to lipid peroxidation, consume relatively large amounts of oxygen for energy production, and have lower antioxidant defenses than other organs. ${ }^{139}$ As a result, the brain is believed to be particularly vulnerable to oxidative stress. However, we hypothesize that under chronic hypertriglyceridemia, the brain might develop compensatory mechanisms (e.g., mitochondrial adaptations) against an abnormal metabolic status that likely exerts protective functions during or after ischemic stroke.

\section{Conclusions and future prospects}

As an increasing number of well-conducted studies have unveiled the relationship between plasma TGs and the risk of ischemic stroke, ${ }^{43,44,140-142}$ we believe that hypertriglyceridemia is a neglected risk factor for ischemic stroke. In this review, we have summarized the possible mechanisms by which hypertriglyceridemia is related to ischemic stroke, including the increased propensity for atherogenesis and thrombosis and the status of blood hyperviscosity. Notably, these three mechanisms are not exclusive and crosstalk with each other. However, there is a huge gap in the interpretation of rare and scattered experimental studies with observations from large prospective clinical studies. Therefore, further targeted and systemic studies are needed to confirm the role of hypertriglyceridemia in promoting the onset of ischemic stroke. Clinically, because nonfasting TGs are more strongly associated with ischemic stroke (as well as other cardiovascular diseases) than fasting TGs, ${ }^{44,45,143}$ the standardized measurement of nonfasting TGs to predict the risk of cardiovascular diseases may be more reasonable. ${ }^{44,143,144}$ In addition, the role of hypertriglyceridemia during and after the period of stroke is unclear and requires further research. Given the inverse correlation between TG levels and stroke outcomes, ${ }^{49-52}$ it is important to determine whether TGs play a protective role in patients with stroke, which may be important for clinical care and secondary prevention.

\section{Disclosure}

The authors have no financial conflicts of interest.

\section{Acknowledgments}

This work was supported by the National Key Research and Development Program (2019YFE0113500) and the National Natural Science Foundation of China (No. 81770268 and U1803125).

\section{References}

1. Campbell BC, De Silva DA, Macleod MR, Coutts SB, Schwamm LH, Davis SM, et al. Ischaemic stroke. Nat Rev Dis Primers 2019;5:70.

2. Kuriakose D, Xiao Z. Pathophysiology and treatment of stroke: present status and future perspectives. Int J Mol Sci 2020;21:7609.

3. Goldstein LB, Bushnell CD, Adams RJ, Appel $\sqcup$, Braun LT, Chaturvedi $S$, et al. Guidelines for the primary prevention of stroke: a guideline for healthcare professionals from the American Heart Association/American Stroke Association. Stroke 2011;42:517-584.

4. Kernan WN, Ovbiagele B, Black HR, Bravata DM, Chimowitz 
MI, Ezekowitz MD, et al. Guidelines for the prevention of stroke in patients with stroke and transient ischemic attack: a guideline for healthcare professionals from the American Heart Association/American Stroke Association. Stroke 2014;45:2160-2236.

5. Sacco RL, Diener HC, Yusuf S, Cotton D, Ounpuu S, Lawton WA, et al. Aspirin and extended-release dipyridamole versus clopidogrel for recurrent stroke. N Engl J Med 2008;359:12381251.

6. Röther J, Alberts MJ, Touzé E, Mas JL, Hill MD, Michel P, et al. Risk factor profile and management of cerebrovascular patients in the REACH Registry. Cerebrovasc Dis 2008;25:366374.

7. Glasser SP, Mosher A, Howard G, Banach M. What is the association of lipid levels and incident stroke? Int J Cardiol 2016;220:890-894.

8. Sun L, Clarke R, Bennett D, Guo Y, Walters RG, Hill M, et al. Causal associations of blood lipids with risk of ischemic stroke and intracerebral hemorrhage in Chinese adults. Nat Med 2019;25:569-574.

9. Stamler J, Neaton JD, Cohen JD, Cutler J, Eberly L, Grandits $G$, et al. Multiple risk factor intervention trial revisited: a new perspective based on nonfatal and fatal composite endpoints, coronary and cardiovascular, during the trial. J Am Heart Assoc 2012;1:e003640.

10. Castilla-Guerra L, Fernández-Moreno Mdel C, López-Chozas $J M$. Statins in the secondary prevention of stroke: new evidence from the SPARCL Study. Clin Investig Arterioscler 2016;28:202-208.

11. Tramacere I, Boncoraglio GB, Banzi R, Del Giovane C, Kwag $\mathrm{KH}$, Squizzato $\mathrm{A}$, et al. Comparison of statins for secondary prevention in patients with ischemic stroke or transient ischemic attack: a systematic review and network meta-analysis. BMC Med 2019;17:67.

12. Aznaouridis K, Masoura C, Vlachopoulos C, Tousoulis D. Statins in stroke. Curr Med Chem 2019;26:6174-6185.

13. Hindy G, Engström G, Larsson SC, Traylor M, Markus HS, Melander 0 , et al. Role of blood lipids in the development of ischemic stroke and its subtypes: a Mendelian randomization study. Stroke 2018;49:820-827.

14. Holmes MV, Millwood IY, Kartsonaki C, Hill MR, Bennett DA, Boxall $R$, et al. Lipids, lipoproteins, and metabolites and risk of myocardial infarction and stroke. J Am Coll Cardiol 2018; $71: 620-632$.

15. Hassing HC, Surendran RP, Mooij HL, Stroes ES, Nieuwdorp M, Dallinga-Thie GM. Pathophysiology of hypertriglyceridemia. Biochim Biophys Acta 2012;1821:826-832.

16. Imaizumi $K_{1}$ Fainaru $M$, Havel RJ. Composition of proteins of mesenteric lymph chylomicrons in the rat and alterations produced upon exposure of chylomicrons to blood serum and serum proteins. J Lipid Res 1978;19:712-722.

17. Zilversmit DB. Atherogenesis: a postprandial phenomenon. Circulation 1979;60:473-485.

18. Cooper AD. Hepatic uptake of chylomicron remnants. J Lipid Res 1997;38:2173-2192.

19. Mahley RW, Huang Y. Atherogenic remnant lipoproteins: role for proteoglycans in trapping, transferring, and internalizing. J Clin Invest 2007;117:94-98.

20. National Cholesterol Education Program (NCEP) Expert Panel on Detection, Evaluation, and Treatment of High Blood Cholesterol in Adults (Adult Treatment Panel III). Third Report of the National Cholesterol Education Program (NCEP) Expert Panel on Detection, Evaluation, and Treatment of High Blood Cholesterol in Adults (Adult Treatment Panel III) final report. Circulation 2002;106:3143-3421.

21. Harrison CM, Goddard JM, Rittey CD. The use of regional anaesthetic blockade in a child with recurrent erythromelalgia. Arch Dis Child 2003;88:65-66.

22. Brola W, Sobolewski P, Fudala M, Goral A, Kasprzyk M, Szczuchniak $W$, et al. Metabolic syndrome in Polish ischemic stroke patients. J Stroke Cerebrovasc Dis 2015;24:2167-2172.

23. Lee JS, Chang PY, Zhang Y, Kizer JR, Best LG, Howard BV. Triglyceride and HDL-C dyslipidemia and risks of coronary heart disease and ischemic stroke by glycemic dysregulation status: the strong heart study. Diabetes Care 2017;40:529-537.

24. Gu X, Li Y, Chen S, Yang X, Liu F, Li Y, et al. Association of lipids with ischemic and hemorrhagic stroke: a prospective cohort study among 267500 Chinese. Stroke 2019;50:33763384.

25. Cui 0 , Naikoo NA. Modifiable and non-modifiable risk factors in ischemic stroke: a meta-analysis. Afr Health Sci 2019; 19:2121-2129.

26. Liu $X$, Yan L, Xue F. The associations of lipids and lipid ratios with stroke: a prospective cohort study. J Clin Hypertens (Greenwich) 2019;21:127-135.

27. Toth PP, Granowitz C, Hull M, Liassou D, Anderson A, Philip S. High triglycerides are associated with increased cardiovascular events, medical costs, and resource use: a real-world administrative claims analysis of statin-treated patients with high residual cardiovascular risk. J Am Heart Assoc 2018;7:e008740.

28. Shin DW, Lee KB, Seo JY, Kim JS, Roh H, Ahn MY, et al. Association between hypertriglyceridemia and lacunar infarction in type 2 diabetes mellitus. J Stroke Cerebrovasc Dis 2015;24: 1873-1878.

29. Nichols GA, Philip S, Reynolds K, Granowitz CB, Fazio S. Increased residual cardiovascular risk in patients with diabetes 
and high versus normal triglycerides despite statin-controlled LDL cholesterol. Diabetes Obes Metab 2019;21:366-371.

30. Ren Y, Ren Q, Lu J, Guo X, Huo X, Ji L, et al. Low triglyceride as a marker for increased risk of cardiovascular diseases in patients with long-term type 2 diabetes: a cross-sectional survey in China. Diabetes Metab Res Rev 2018;34:e2960.

31. Sultan $S$, Dowling $M$, Kirton $A$, DeVeber G, Linds A, Elkind MS, et al. Dyslipidemia in children with arterial ischemic stroke: prevalence and risk factors. Pediatr Neurol 2018;78:46-54.

32. Lee H, Park JB, Hwang IC, Yoon YE, Park HE, Choi SY, et al. Association of four lipid components with mortality, myocardial infarction, and stroke in statin-naïve young adults: a nationwide cohort study. Eur J Prev Cardiol 2020;27:870-881.

33. Huang YQ, Huang JY, Liu L, Chen CL, Yu YL, Tang ST, et al. Relationship between triglyceride levels and ischaemic stroke in elderly hypertensive patients. Postgrad Med J 2020;96: 128-133.

34. Wang W, Shen C, Zhao H, Tang W, Yang S, Li J, et al. A prospective study of the hypertriglyceridemic waist phenotype and risk of incident ischemic stroke in a Chinese rural population. Acta Neurol Scand 2018;138:156-162.

35. Saeed A, Feofanova EV, Yu B, Sun W, Virani SS, Nambi V, et al. Remnant-like particle cholesterol, low-density lipoprotein triglycerides, and incident cardiovascular disease. J Am Coll Cardiol 2018;72:156-169.

36. Morrison AC, Ballantyne CM, Bray M, Chambless LE, Sharrett $A R$, Boerwinkle E. LPL polymorphism predicts stroke risk in men. Genet Epidemiol 2002;22:233-242.

37. Munshi A, Babu MS, Kaul S, Rajeshwar K, Balakrishna N, Jyothy A. Association of LPL gene variant and LDL, HDL, VLDL cholesterol and triglyceride levels with ischemic stroke and its subtypes. J Neurol Sci 2012;318:51-54.

38. Pi Y, Zhang L, Yang Q, Li B, Guo L, Fang C, et al. Apolipoprotein $\mathrm{A} 5$ gene promoter region-1131T/C polymorphism is associated with risk of ischemic stroke and elevated triglyceride levels: a meta-analysis. Cerebrovasc Dis 2012;33:558-565.

39. Nichols GA, Philip S, Reynolds K, Granowitz CB, Fazio S. Increased cardiovascular risk in hypertriglyceridemic patients with statin-controlled LDL cholesterol. J Clin Endocrinol Metab 2018;103:3019-3027.

40. Toth PP, Philip S, Hull M, Granowitz C. Association of elevated triglycerides with increased cardiovascular risk and direct costs in statin-treated patients. Mayo Clin Proc 2019;94:16701680.

41. Wang A, Li H, Yuan J, Zuo Y, Zhang Y, Chen S, et al. Visit-to-visit variability of lipids measurements and the risk of stroke and stroke types: a prospective cohort study. J Stroke 2020;22:119-129.
42. Kivioja R, Pietilä A, Martinez-Majander N, Gordin D, Havulinna AS, Salomaa $V$, et al. Risk factors for early-onset ischemic stroke: a case-control study. J Am Heart Assoc 2018;7:e009774.

43. Bansal S, Buring JE, Rifai N, Mora S, Sacks FM, Ridker PM. Fasting compared with nonfasting triglycerides and risk of cardiovascular events in women. JAMA 2007;298:309-316.

44. Freiberg JJ, Tybjaerg-Hansen A, Jensen JS, Nordestgaard BG. Nonfasting triglycerides and risk of ischemic stroke in the general population. JAMA 2008;300:2142-2152.

45. Varbo A, Nordestgaard BG, Tybjaerg-Hansen A, Schnohr $P$, Jensen GB, Benn M. Nonfasting triglycerides, cholesterol, and ischemic stroke in the general population. Ann Neurol 2011; 69:628-634.

46. Iso $H$, Imano $H$, Yamagishi $K$, Ohira $T$, Cui $R$, Noda $H$, et al. Fasting and non-fasting triglycerides and risk of ischemic cardiovascular disease in Japanese men and women: the Circulatory Risk in Communities Study (CIRCS). Atherosclerosis 2014;237:361-368.

47. Tada $H_{1}$ Nomura $A$, Yoshimura $K_{1}$ Itoh $H$, Komuro I, Yamagishi $M$, et al. Fasting and non-fasting triglycerides and risk of cardiovascular events in diabetic patients under statin therapy. Circ J 2020;84:509-515.

48. Tziomalos K, Giampatzis V, Bouziana SD, Spanou M, Kostaki $\mathrm{S}$, Papadopoulou $\mathrm{M}$, et al. Prognostic significance of major lipids in patients with acute ischemic stroke. Metab Brain Dis 2017;32:395-400.

49. Dziedzic T, Slowik A, Gryz EA, Szczudlik A. Lower serum triglyceride level is associated with increased stroke severity. Stroke 2004;35:e151-e152.

50. Ryu WS, Lee SH, Kim CK, Kim BJ, Yoon BW. Effects of low serum triglyceride on stroke mortality: a prospective follow-up study. Atherosclerosis 2010;212:299-304.

51. Weir CJ, Sattar N, Walters MR, Lees KR. Low triglyceride, not low cholesterol concentration, independently predicts poor outcome following acute stroke. Cerebrovasc Dis 2003;16: 76-82.

52. Pikija S, Milevcić D, Trkulja V, Kidemet-Piskac S, Pavlicek I, Sokol N. Higher serum triglyceride level in patients with acute ischemic stroke is associated with lower infarct volume on CT brain scans. Eur Neurol 2006;55:89-92.

53. Zhao $Y$, Yang $C$, Yan $X, M a X$, Wang $X$, Zou $C$, et al. Prognosis and associated factors among elderly patients with small artery occlusion. Sci Rep 2019;9:15380.

54. Liu L, Zhan L, Wang Y, Bai C, Guo J, Lin Q, et al. Metabolic syndrome and the short-term prognosis of acute ischemic stroke: a hospital-based retrospective study. Lipids Health Dis 2015;14:76

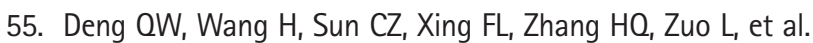


Triglyceride to high-density lipoprotein cholesterol ratio predicts worse outcomes after acute ischaemic stroke. Eur $J$ Neurol 2017;24:283-291.

56. Deng OW, Li S, Wang H, Lei L, Zhang HQ, Gu ZT, et al. The short-term prognostic value of the triglyceride-to-high-density lipoprotein cholesterol ratio in acute ischemic stroke. Aging Dis 2018;9:498-506.

57. Kang K, Lee JJ, Park JM, Kwon O, Han SW, Kim BK. High nonfasting triglyceride concentrations predict good outcome following acute ischaemic stroke. Neurol Res 2017;39:779-786.

58. Deng Q, Li S, Zhang H, Wang H, Gu Z, Zuo L, et al. Association of serum lipids with clinical outcome in acute ischaemic stroke: a systematic review and meta-analysis. J Clin Neurosci 2019;59:236-244.

59. Celap I, Nikolac Gabaj N, Demarin V, Basic Kes V, Simundic AM. Genetic and lifestyle predictors of ischemic stroke severity and outcome. Neurol Sci 2019;40:2565-2572.

60. Xu T, Zhang JT, Yang M, Zhang H, Liu WQ, Kong Y, et al. Dyslipidemia and outcome in patients with acute ischemic stroke. Biomed Environ Sci 2014;27:106-110.

61. Li $X$, Li X, Fang F, Fu X, Lin H, Gao O. Is metabolic syndrome associated with the risk of recurrent stroke: a meta-analysis of cohort studies. J Stroke Cerebrovasc Dis 2017;26:2700-2705.

62. Chen Y, Liu P, Qi R, Wang YH, Liu G, Wang C. Severe hypertriglyceridemia does not protect from ischemic brain injury in gene-modified hypertriglyceridemic mice. Brain Res 2016; 1639:161-173.

63. Bloomfield Rubins H, Davenport J, Babikian V, Brass LM, Collins $D$, Wexler $L$, et al. Reduction in stroke with gemfibrozil in men with coronary heart disease and low HDL cholesterol: the Veterans Affairs HDL Intervention Trial (VA-HIT). Circulation 2001;103:2828-2833.

64. Bhatt DL, Steg PG, Miller M, Brinton EA, Jacobson TA, Ketchum SB, et al. Cardiovascular risk reduction with icosapent ethyl for hypertriglyceridemia. N Engl J Med 2019; 380:11-22.

65. Smith WS, English JD, Johnston SC. Cerebrovascular diseases. In: Longo DL, Fauci A, Kasper D, Hauser S, Jameson JL, Loscalzo J. Harrison's Principles of Internal Medicine. 18th ed. New York, NY: McGraw-Hill, 2012:3270-3299.

66. Boquist $\mathrm{S}$, Ruotolo G, Tang R, Björkegren J, Bond MG, de Faire $\mathrm{U}$, et al. Alimentary lipemia, postprandial triglyceride-rich lipoproteins, and common carotid intima-media thickness in healthy, middle-aged men. Circulation 1999;100:723-728.

67. Mori Y, Itoh Y, Komiya H, Tajima N. Association between postprandial remnant-like particle triglyceride (RLP-TG) levels and carotid intima-media thickness (IMT) in Japanese patients with type 2 diabetes: assessment by meal tolerance tests (MTT). Endocrine 2005;28:157-163.

68. Boullart AC, de Graaf J, Stalenhoef AF. Serum triglycerides and risk of cardiovascular disease. Biochim Biophys Acta 2012;1821:867-875.

69. Nordestgaard BG, Zilversmit DB. Large lipoproteins are excluded from the arterial wall in diabetic cholesterol-fed rabbits. J Lipid Res 1988;29:1491-1500.

70. Daugherty A, Lange LG, Sobel BE, Schonfeld G. Aortic accumulation and plasma clearance of beta-VLDL and HDL: effects of diet-induced hypercholesterolemia in rabbits. J Lipid Res 1985;26:955-963.

71. Rapp JH, Lespine A, Hamilton RL, Colyvas $N_{1}$ Chaumeton $A H$, Tweedie-Hardman J, et al. Triglyceride-rich lipoproteins isolated by selected-affinity anti-apolipoprotein B immunosorption from human atherosclerotic plaque. Arterioscler Thromb 1994;14:1767-1774.

72. Proctor SD, Mamo JC. Intimal retention of cholesterol derived from apolipoprotein B100- and apolipoprotein B48-containing lipoproteins in carotid arteries of Watanabe heritable hyperlipidemic rabbits. Arterioscler Thromb Vasc Biol 2003;23:1595-1600.

73. Nordestgaard BG, Wootton R, Lewis B. Selective retention of $V L D L, I D L$, and LDL in the arterial intima of genetically hyperlipidemic rabbits in vivo: molecular size as a determinant of fractional loss from the intima-inner media. Arterioscler Thromb Vasc Biol 1995;15:534-542.

74. Schwartz EA, Reaven PD. Lipolysis of triglyceride-rich lipoproteins, vascular inflammation, and atherosclerosis. Biochim Biophys Acta 2012;1821:858-866.

75. Nakamura T, Obata JE, Takano H, Kawabata K, Sano K, Kobayashi $T$, et al. High serum levels of remnant lipoproteins predict ischemic stroke in patients with metabolic syndrome and mild carotid atherosclerosis. Atherosclerosis 2009;202: 234-240.

76. Wilhelm MG, Cooper AD. Induction of atherosclerosis by human chylomicron remnants: a hypothesis. J Atheroscler Thromb 2003;10:132-139.

77. Hennig B, Toborek M, McClain CJ. High-energy diets, fatty acids and endothelial cell function: implications for atherosclerosis. J Am Coll Nutr 2001;20(2 Suppl):97-105.

78. Eiselein L, Wilson DW, Lamé MW, Rutledge JC. Lipolysis products from triglyceride-rich lipoproteins increase endothelial permeability, perturb zonula occludens- 1 and F-actin, and induce apoptosis. Am J Physiol Heart Circ Physiol 2007;292:H2745-H2753.

79. Wang L, Gill R, Pedersen TL, Higgins $\sqcup$, Newman JW, Rutledge JC. Triglyceride-rich lipoprotein lipolysis releases neutral and oxidized FFAs that induce endothelial cell inflamma- 
tion. J Lipid Res 2009;50:204-213.

80. Nicolson GL. Metabolic syndrome and mitochondrial function: molecular replacement and antioxidant supplements to prevent membrane peroxidation and restore mitochondrial function. J Cell Biochem 2007;100:1352-1369.

81. Lupattelli G, Lombardini R, Schillaci G, Ciuffetti G, Marchesi $S$, Siepi $D$, et al. Flow-mediated vasoactivity and circulating adhesion molecules in hypertriglyceridemia: association with small, dense LDL cholesterol particles. Am Heart J 2000;140: 521-526.

82. Lundman $P$, Eriksson $M$, Schenck-Gustafsson $K$, Karpe $F$, Tornvall P. Transient triglyceridemia decreases vascular reactivity in young, healthy men without risk factors for coronary heart disease. Circulation 1997;96:3266-3268.

83. Vogel RA, Corretti MC, Plotnick GD. Effect of a single highfat meal on endothelial function in healthy subjects. $\mathrm{Am} \mathrm{J}$ Cardiol 1997;79:350-354.

84. Gudmundsson GS, Sinkey CA, Chenard CA, Stumbo PJ, Haynes WG. Resistance vessel endothelial function in healthy humans during transient postprandial hypertriglyceridemia. Am J Cardiol 2000;85:381-385.

85. Lewis TV, Dart AM, Chin-Dusting JP. Endothelium-dependent relaxation by acetylcholine is impaired in hypertriglyceridemic humans with normal levels of plasma LDL cholesterol. J Am Coll Cardiol 1999;33:805-812.

86. Yunoki K, Nakamura K, Miyoshi T, Enko K, Kubo M, Murakami $M$, et al. Impact of hypertriglyceridemia on endothelial dysfunction during statin \pm ezetimibe therapy in patients with coronary heart disease. Am J Cardiol 2011;108:333-339.

87. Nagashima $H$, Endo M. Pitavastatin prevents postprandial endothelial dysfunction via reduction of the serum triglyceride level in obese male subjects. Heart Vessels 2011;26:428434.

88. Bae JH, Bassenge $\mathrm{E}, \mathrm{Kim} \mathrm{KB}, \mathrm{Kim}$ YN, Kim KS, Lee HJ, et al. Postprandial hypertriglyceridemia impairs endothelial function by enhanced oxidant stress. Atherosclerosis 2001;155:517523.

89. Anderson RA, Evans ML, Ellis GR, Graham J, Morris K, Jackson SK, et al. The relationships between post-prandial lipaemia, endothelial function and oxidative stress in healthy individuals and patients with type 2 diabetes. Atherosclerosis 2001; 154:475-483.

90. Kawasaki S, Taniguchi T, Fujioka Y, Takahashi A, Takahashi T, Domoto $\mathrm{K}$, et al. Chylomicron remnant induces apoptosis in vascular endothelial cells. Ann N Y Acad Sci 2000;902:336-341.

91. Abe Y, El-Masri B, Kimball KT, Pownall H, Reilly CF, Osmund-

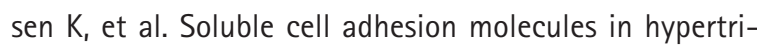
glyceridemia and potential significance on monocyte adhe- sion. Arterioscler Thromb Vasc Biol 1998;18:723-731.

92. Benítez MB, Cuniberti L, Fornari MC, Gómez Rosso L, Berardi V, Elikir G, et al. Endothelial and leukocyte adhesion molecules in primary hypertriglyceridemia. Atherosclerosis 2008;197: 679-687.

93. Kashyap SR, Belfort R, Cersosimo E, Lee S, Cusi K. Chronic low-dose lipid infusion in healthy patients induces markers of endothelial activation independent of its metabolic effects. J Cardiometab Syndr 2008;3:141-146.

94. Zernecke $A$, Shagdarsuren $E$, Weber $C$. Chemokines in atherosclerosis: an update. Arterioscler Thromb Vasc Biol 2008; 28:1897-1908.

95. Maeno Y, Kashiwagi A, Nishio Y, Takahara N, Kikkawa R. IDL can stimulate atherogenic gene expression in cultured human vascular endothelial cells. Diabetes Res Clin Pract 2000; 48:127-138.

96. Park SY, Lee JH, Kim YK, Kim CD, Rhim BY, Lee WS, et al. Cilostazol prevents remnant lipoprotein particle-induced monocyte adhesion to endothelial cells by suppression of adhesion molecules and monocyte chemoattractant protein-1 expression via lectin-like receptor for oxidized low-density lipoprotein receptor activation. J Pharmacol Exp Ther 2005;312:1241-1248.

97. Domoto K, Taniguchi T, Takaishi H, Takahashi T, Fujioka Y,

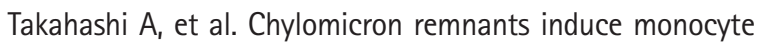
chemoattractant protein-1 expression via p38 MAPK activation in vascular smooth muscle cells. Atherosclerosis 2003; 171:193-200.

98. Gower RM, Wu H, Foster GA, Devaraj S, Jialal I, Ballantyne CM, et al. CD11c/CD18 expression is upregulated on blood monocytes during hypertriglyceridemia and enhances adhesion to vascular cell adhesion molecule-1. Arterioscler Thromb Vasc Biol 2011;31:160-166.

99. Kawakami A, Tanaka A, Nakajima K, Shimokado K, Yoshida $M$. Atorvastatin attenuates remnant lipoprotein-induced monocyte adhesion to vascular endothelium under flow conditions. Circ Res 2002;91:263-271.

100. Dichtl W, Nilsson L, Goncalves I, Ares MP, Banfi C, Calara F, et al. Very low-density lipoprotein activates nuclear factor-kappaB in endothelial cells. Circ Res 1999;84:1085-1094.

101. Wang L, Lim E, Toborek M, Hennig B. The role of fatty acids and caveolin-1 in tumor necrosis factor alpha-induced endothelial cell activation. Metabolism 2008;57:1328-1339.

102. Antonios N, Angiolillo DJ, Silliman S. Hypertriglyceridemia and ischemic stroke. Eur Neurol 2008;60:269-278.

103. Scirica BM, Morrow DA. Is C-reactive protein an innocent bystander or proatherogenic culprit?: the verdict is still out. Circulation 2006;113:2128-2134. 
104. Schunkert H, Samani NJ. Elevated C-reactive protein in atherosclerosis: chicken or egg? N Engl J Med 2008;359:19531955.

105. Verma S, Devaraj S, Jialal I. Is C-reactive protein an innocent bystander or proatherogenic culprit?: C-reactive protein promotes atherothrombosis. Circulation 2006;113:2135-2150.

106. Pepys MB, Hirschfield GM, Tennent GA, Gallimore JR, Kahan MC, Bellotti V, et al. Targeting C-reactive protein for the treatment of cardiovascular disease. Nature 2006;440:12171221.

107. Rosenson RS, Shott S, Tangney CC. Hypertriglyceridemia is associated with an elevated blood viscosity Rosenson: triglycerides and blood viscosity. Atherosclerosis 2002;161: 433-439.

108. Késmárky $G$, Kenyeres $P$, Rábai $M$, Tóth K. Plasma viscosity: a forgotten variable. Clin Hemorheol Microcirc 2008;39:243246.

109. Zhao T, Guo J, Li H, Huang W, Xian X, Ross CJ, et al. Hemorheological abnormalities in lipoprotein lipase deficient mice with severe hypertriglyceridemia. Biochem Biophys Res Commun 2006;341:1066-1071.

110. Vayá $A$, Hernández-Mijares $A$, Bonet $E_{1}$ Sendra $R$, Solá $E_{1}$ Pérez $R$, et al. Association between hemorheological alterations and metabolic syndrome. Clin Hemorheol Microcirc 2011;49:493-503.

111. Leonhardt H, Arntz HR, Klemens UH. Studies of plasma viscosity in primary hyperlipoproteinaemia. Atherosclerosis 1977;28:29-40.

112. Seplowitz AH, Chien S, Smith FR. Effects of lipoproteins on plasma viscosity. Atherosclerosis 1981;38:89-95.

113. Lee AJ, Mowbray PI, Lowe GD, Rumley A, Fowkes FG, Allan PL. Blood viscosity and elevated carotid intima-media thickness in men and women: the Edinburgh Artery Study. Circulation 1998;97:1467-1473.

114. Lowe GD, Lee AJ, Rumley A, Price JF, Fowkes FG. Blood viscosity and risk of cardiovascular events: the Edinburgh Artery Study. Br J Haematol 1997;96:168-173.

115. Tikhomirova IA, Oslyakova AO, Mikhailova SG. Microcirculation and blood rheology in patients with cerebrovascular disorders. Clin Hemorheol Microcirc 2011;49:295-305.

116. Hu F, Alcasabas AA, Elledge SJ. Asf1 links Rad53 to control of chromatin assembly. Genes Dev 2001;15:1061-1066.

117. Furie $B$, Furie BC. Mechanisms of thrombus formation. N Engl J Med 2008;359:938-949.

118. Simpson HC, Mann Jl, Meade TW, Chakrabarti R, Stirling Y, Woolf L. Hypertriglyceridaemia and hypercoagulability. Lancet 1983;1:786-790.

119. Andersen P. Hypercoagulability and reduced fibrinolysis in hy- perlipidemia: relationship to the metabolic cardiovascular syndrome. J Cardiovasc Pharmacol 1992;20 Suppl 8:S29-S31.

120. Silveira A. Postprandial triglycerides and blood coagulation. Exp Clin Endocrinol Diabetes 2001;109:S527-S532.

121. Negri $M$, Arigliano $P L$, Talamini G, Carlini S, Manzato $F$, Bonadonna G. Levels of plasma factor VII and factor VII activated forms as a function of plasma triglyceride levels. Atherosclerosis 1993;99:55-61.

122. Ohni M, Mishima $K$, Nakajima $K$, Yamamoto $M$, Hata $Y$. Serum triglycerides and blood coagulation factors VII and $X_{1}$ and plasminogen activator inhibitor-1. J Atheroscler Thromb 1995;2 Suppl 1:S41-S46.

123. Chan P, Huang TY, Shieh SM, Lin TS, Tsai CW. Thrombophilia in patients with hypertriglyceridemia. J Thromb Thrombolysis 1997;4:425-429.

124. Carvalho de Sousa J, Bruckert E, Giral P, Soria C, Chapman J, Truffert J, et al. Coagulation factor VII and plasma triglycerides: decreased catabolism as a possible mechanism of factor VII hyperactivity. Haemostasis 1989;19:125-130.

125. Minnema MC, Wittekoek ME, Schoonenboom N, Kastelein JJ,

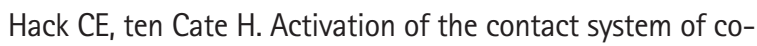
agulation does not contribute to the hemostatic imbalance in hypertriglyceridemia. Arterioscler Thromb Vasc Biol 1999; 19:2548-2553.

126. Mussoni $L$, Mannucci $L$, Sirtori $M$, Camera $M$, Maderna $P$, Sironi $L$, et al. Hypertriglyceridemia and regulation of fibrinoIytic activity. Arterioscler Thromb 1992;12:19-27.

127. Hiraga T, Shimada M, Tsukada T, Murase T. Hypertriglyceridemia, but not hypercholesterolemia, is associated with the alterations of fibrinolytic system. Horm Metab Res 1996;28: 603-606.

128. Byberg L, Smedman A, Vessby B, Lithell H. Plasminogen activator inhibitor- 1 and relations to fatty acid composition in the diet and in serum cholesterol esters. Arterioscler Thromb Vasc Biol 2001;21:2086-2092.

129. Tholstrup T, Miller GJ, Bysted A, Sandström B. Effect of individual dietary fatty acids on postprandial activation of blood coagulation factor VII and fibrinolysis in healthy young men. Am J Clin Nutr 2003;77:1125-1132.

130. Mitropoulos KA, Miller GJ, Watts GF, Durrington PN. Lipolysis of triglyceride-rich lipoproteins activates coagulant factor XII: a study in familial lipoprotein-lipase deficiency. Atherosclerosis 1992;95:119-125.

131. Stiko-Rahm A, Wiman B, Hamsten A, Nilsson J. Secretion of plasminogen activator inhibitor-1 from cultured human umbilical vein endothelial cells is induced by very low density lipoprotein. Arteriosclerosis 1990;10:1067-1073.

132. Kaneko T, Wada H, Wakita $Y$, Minamikawa $K$, Nakase T, Mori 
$Y_{1}$ et al. Enhanced tissue factor activity and plasminogen activator inhibitor-1 antigen in human umbilical vein endothelial cells incubated with lipoproteins. Blood Coagul Fibrinolysis 1994;5:385-392.

133. Sironi L, Mussoni L, Prati L, Baldassarre D, Camera M, Banfi

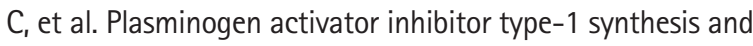
mRNA expression in HepG2 cells are regulated by VLDL. Arterioscler Thromb Vasc Biol 1996;16:89-96.

134. Morimoto $S$, Fujioka $Y$, Hosoai $H$, Okumura T, Masai M, Sakoda $T$, et al. The renin-angiotensin system is involved in the production of plasminogen activator inhibitor type 1 by cultured endothelial cells in response to chylomicron remnants. Hypertens Res 2003;26:315-323.

135. De Man FH, Nieuwland $R$, van der Laarse A, Romijn F, Smelt $\mathrm{AH}$, Gevers Leuven JA, et al. Activated platelets in patients with severe hypertriglyceridemia: effects of triglyceride-lowering therapy. Atherosclerosis 2000;152:407-414.

136. Jeng JR, Jeng CY, Sheu WH, Lee MM, Huang SH, Shieh SM. Gemfibrozil treatment of hypertriglyceridemia: improvement on fibrinolysis without change of insulin resistance. Am Heart J 1997;134:565-571.

137. Listenberger LL, Han $X$, Lewis $S E$, Cases $S$, Farese RV Jr, Ory $D S$, et al. Triglyceride accumulation protects against fatty acid-induced lipotoxicity. Proc Natl Acad Sci U S A 2003;100: 3077-3082.

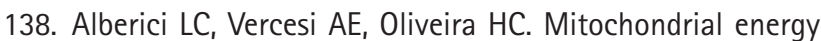
metabolism and redox responses to hypertriglyceridemia. $J$ Bioenerg Biomembr 2011;43:19-23.

139. Adibhatla RM, Hatcher JF. Altered lipid metabolism in brain injury and disorders. Subcell Biochem 2008;49:241-268.

140. Patel A, Barzi F, Jamrozik $K$, Lam TH, Ueshima $H$, Whitlock $G$, et al. Serum triglycerides as a risk factor for cardiovascular diseases in the Asia-Pacific region. Circulation 2004;110:2678-2686.

141. Labreuche J, Deplanque D, Touboul PJ, Bruckert E, Amarenco P. Association between change in plasma triglyceride levels and risk of stroke and carotid atherosclerosis: systematic review and meta-regression analysis. Atherosclerosis 2010;212: 9-15.

142. Berger JS, McGinn AP, Howard BV, Kuller L, Manson JE, Otvos $J$, et al. Lipid and lipoprotein biomarkers and the risk of ischemic stroke in postmenopausal women. Stroke 2012;43:958966.

143. Ridker PM. Fasting versus nonfasting triglycerides and the prediction of cardiovascular risk: do we need to revisit the oral triglyceride tolerance test? Clin Chem 2008;54:11-13.

144. Ebinger $M$, Heuschmann PU, Jungehuelsing GJ, Werner $C$, Laufs U, Endres M. The Berlin 'Cream\&Sugar' Study: the prognostic impact of an oral triglyceride tolerance test in patients after acute ischaemic stroke. Int J Stroke 2010;5: 126-130. 